LIVER

\title{
Severe hepatic injury in interleukin 18 (IL-18) transgenic mice: a key role for IL-18 in regulating hepatocyte apoptosis in vivo
}

\author{
S Finotto, J Siebler, M Hausding, M Schipp, S Wirtz, S Klein, M Protschka, A Doganci, H A Lehr, \\ C Trautwein, R Khosravi-Fahr, D Strand, A Lohse, P R Galle, M Blessing, M F Neurath
}

See end of article for authors' affiliations

......................

Correspondence to:

Dr S Finotto, Laboratory of Immunology, I Medical Clinic, Johannes

Gutenberg-University of

Mainz, Germany; finotto@

mail.uni-mainz.de

Accepted for publication 17 September 2003

\begin{abstract}
Background: Interleukin 18 (IL-18) is a cytokine with pleiotropic activity that augments T helper 1 responses and cytotoxic activity of natural killer cells.

Methods: To assess the function of IL-18 in vivo, we generated IL-18 transgenic (IL-18 Tg) mice under the control of a CD2 promoter/enhancer construct.

Results: Macroscopically, IL-18 Tg mice showed reduced relative liver weight compared with wild-type littermates. TUNEL assays demonstrated increased hepatocyte apoptosis, and primary hepatocytes isolated from IL-18 Tg mice exhibited an increased spontaneous apoptosis rate. Furthermore, cross linking of Fas increased significantly the apoptosis rate in hepatocytes isolated from wild- type mice but to a much lesser extent in IL-18 Tg mice, suggesting spontaneous activation of the Fas pathway in the latter mice. In fact, in vivo blockade of Fas signal transduction by an adenovirus overexpressing the dominant negative form of the Fas associated death domain rescued hepatocytes from undergoing apoptosis. Finally, adoptive transfer of $\mathrm{CD} 4^{+} \mathrm{T}$ cells from IL-18 Tg mice but not from wild-type littermates in SCID mice resulted in severe liver failure with massive periportal fibrosis due to hepatocyte apoptosis.

Conclusion: IL-18 plays a fundamental role in regulating hepatocyte apoptosis. Furthermore, our transgenic model provides a novel tool to study the mechanisms of IL-18 dependent liver injury in vivo.
\end{abstract}

$\mathrm{T}$ he pleiotropic cytokine interleukin 18 (IL-18) is a member of the IL-1 family that was originally described as an inducer of interferon $\gamma($ IFN- $\gamma)$ production from $\mathrm{T}$ cells in the presence of IL- 12 (interferon $\gamma$ inducing factor). ${ }^{1-8}$ IL-18 is produced by Kupffer cells, macrophages, B cells, and dendritic cells on lipopolysaccharide (LPS) stimulation. ${ }^{9}$ It has been identified and cloned from cDNA extracted from the liver of mice infected with Propionibacterium acnes. Sequential treatment with heat killed $P$ acnes and LPS induces IL-18 dependent acute liver injury in mice, probably through upregulation of Fas ligand. ${ }^{1}$ Conversely, treatment with a neutralising antibody to IL-18 protects against such liver injury, and IL-18 deficient mice were resistant to $P$ acnes and LPS induced liver injury, indicating that IL-18 plays a critical role in $P$ acnes and LPS induced liver injury. ${ }^{1}{ }^{10} 11$

In common with IL-1 $\beta$, IL-18 is intracellularly produced as a biologically inactive precursor protein (pro-IL-18), and mature IL-18 is secreted after cleavage of pro-IL-18 by caspase- 1 , originally designated as IL- $1 \beta$ converting enzyme. ${ }^{12}$ IL-18 mediates its biological function through binding to a specific receptor complex on the cell surface consisting of two chains: a ligand binding chain termed the IL-18Ralpha chain and a signal transducing chain termed the IL-18Rbeta chain. Whereas the IL-18Ralpha chain has a weak affinity for the ligand, the complete IL-18R complex has high binding affinity for IL-18 and is expressed, for example, on T helper $1 \mathrm{~T}$ cells and natural killer (NK) T cells. ${ }^{13-15}$ Binding of IL-18 to the high affinity IL-18R leads to nuclear factor $\kappa \mathrm{B}$ $(\mathrm{NF} \kappa \mathrm{B})$ activation through IL-1 receptor associated kinase, the adaptor proteins MyD88, and tumour necrosis factor (TNF) receptor-associated factor 6, and subsequent phosphorylation of $\mathrm{I} \kappa \mathrm{B}$ via $\mathrm{I} \kappa \mathrm{B}$ kinases (IKK-1, IKK-2). ${ }^{16-18}$ In addition, IL-18 triggers NK cell activity and expression of FasL by NK cells.
Furthermore, IL-18 is a coinducer of IL- 12 driven T helper 1 $\mathrm{T}$ cell differentiation by upregulating IL- 12 receptor beta 2 chain expression and transactivation of the IFN- $\gamma$ promoter via the transcription factor AP- $1 .{ }^{19}$ Finally, IL-18 augments proinflammatory immune responses by upregulating the production of various cytokines such as IL-1, IL-6, and TNF. ${ }^{3}$

The above data prompted us to hypothesise that IL-18 may augment the cytotoxic activity of intrahepatic NK T and NK cells during an immune response. In the present study, we describe generation of IL-18 transgenic (Tg) mice under the control of the CD2 promoter. These mice showed reduced liver weight due to an increase in spontaneous Fas dependent apoptosis of hepatocytes. Furthermore, signal transduction studies in hepatocytes of IL-18 Tg versus wild-type mice showed that NFкB is activated in the nucleus of IL-18 Tg hepatocytes compared with hepatocytes isolated from wildtype mice. Adoptive transfer of $\mathrm{CD}^{+} \mathrm{T}$ cells from IL-18 Tg spleen but not from wild-type littermates in SCID mice resulted in severe liver failure with massive periportal fibrosis and liver inflammation associated with hepatocyte apoptosis. Our data thus suggest a key regulatory role of IL-18 for hepatocyte apoptosis in vivo via a Fas dependent mechanism.

Abbreviations: IL-18, interleukin 18; IL-18R, IL-18 receptor; IL-18 Tg, IL18 transgenic; NK, natural killer; IFN- $\gamma$, interferon $\gamma$; LPS, lipopolysaccharide; $\mathrm{NF} \kappa \mathrm{B}$, nuclear factor $\kappa \mathrm{B}$; TNF, fumour necrosis factor; RT-PCR, reverse transcription-polymerase chain reaction; SAC, Staphylococcus aureus Cowan's antigen; DEAE, diethylaminoethyl; $B M P 6$, bone morphogenetic protein 6; adv, adenoviral vectors; dnFADD, dominant negative Fas associated death domain; $\beta$-Gal, $\beta$ galactosidase; $\mathrm{Pl}$, propidium iodide; TdT, terminal deoxynucleotidyltransferase; TUNEL, TdT mediated fluorescein dUTP nick end labelling 


\section{MATERIALS AND METHODS Vector construct for generation of IL- 18 transgenic mice}

cDNA of IL-18 was obtained after reverse transcription (RT) (First Strand cDNA synthesis kit for RT-polymerase chain reaction (PCR); Roche Applied Science, Mannheim, Germany) of RNA extracted from the monocytic cell line RAW264.7 activated with LPS $(1 \mu \mathrm{g} / \mathrm{ml})$ (Sigma, St Louis, Missouri, USA) and Staphylococcus aureus Cowan's antigen (SAC; $0.001 \%$; Cabiochem, Germany). cDNA for IL-18 was then amplified by 33 PCR cycles using specific oligonucleotide primers $\left(5^{\prime}\right.$ CTC- CCC- ACC- TAA- CTT-TGA-TG-3' and 5' CCA-GGAACA-ATG-GCT-GCC-AT-3'). The PCR product was then subcloned into the polylinker site of the pcDNA 3.1 expression vector (Invitrogen, Heidelberg, Germany) and sequenced. The 595 bp IL-18 cDNA was then subcloned at the SmaI restriction site by blunt end ligation downstream of the CD2 promoter/enhancer construct yielding the CD2-IL-18 plasmid. $^{20}$

\section{Cell transfection}

Transfection experiments were conducted to confirm whether the transgenic construct could induce optimal secretion of mature IL-18 in vitro. The CD2-IL-18 plasmid and the empty vector CD2 were transiently transfected into RAW264.7 and Jurkat T cells. This transfection was carried out using the diethylaminoethyl (DEAE) dextran (GibcoBRL, Karlsruhe, Germany) method, as previously described. ${ }^{21}$ Briefly, $2.5 \times 10^{7}$ cells were incubated for one hour with DEAE-dextran and $10 \mathrm{~g}$ of plasmid at $37^{\circ} \mathrm{C}$. Cells were cultured for an additional 48 hours after transfection; then, total RNA and cellular proteins were extracted from the transfected cells. For IL-18 transcript detection, $1 \mu \mathrm{g}$ of total RNA was reverse transcribed using random primers and RTMV transcriptase (Roche Applied Science). cDNA for IL-18 and $\beta$-actin was then amplified by PCR using the primers described above for IL-18.

Western blot analysis was performed using $7.5 \%$ polyacrylamide gel under reducing conditions. Recombinant murine IL-18 (75 ng) was loaded as a positive control (R\&D System, Wiesbaden, Germany). After protein transfer onto nitrocellulose membranes, IL-18 was detected using a polyclonal antibody made in the goat $(0.4 \mathrm{~g} / \mathrm{ml})$ (R\&D Systems, Wiesbaden, Germany) followed by incubation with the biotinylated antigoat antibody and streptavidin-alkaline phosphatase incubation, and developed using a substrate for alkaline phosphatase (1:30 000) (Dako Diagnostics GmbH, Hamburg, Germany).

\section{Identification of CD2/IL- 18 transgenic mice}

Based on these results, the fragment obtained after digestion, with the restriction enzymes KpnI and Not I, of the CD2-IL-18 construct containing the IL-18 expression cassette was microinjected into pronuclei of fertilised eggs of FVB/NHSD mice. Mice were maintained under specific pathogen free conditions in isolated cages. Founder mice were born and bred separately to generate Fl progeny, resulting in independent lines. Transgenic integration was confirmed in genomic DNA extracted from the ear or tail by overnight digestion in proteinase $\mathrm{K}$ buffer (proteinase $\mathrm{K} 250 \mathrm{~g} / \mathrm{ml}$ ) at $55^{\circ} \mathrm{C}$ followed by PCR for IL- 18 and the bone morphogenetic protein 6 (BMP6) using the following primers: BMP6: 5' GTC TGC AGA TGT GTC TGC GTG TCA CG $3^{\prime}$ and 5' ATG AAT GCC ACC AAC CAC G 3'; IL-18: CD2 upstream 5' CCC AGC TTT CCC TGA AAG TG $3^{\prime}$ and $5^{\prime \prime}$ CTC CCC ACC TAA CTT TGA TG 3' IL-18 downstream primer (see fig lD).

\section{Total RNA extraction and RT-PCR}

Total liver tissue was homogenised in a Polytron homogeniser and RNA was then extracted by resuspending the homogenised tissue in $1 \mathrm{ml}$ of TRI-REAGENT (Sigma) in accordance with the manufacturer's instructions. Addition of chloroform was followed by centrifugation, and RNA was precipitated from the aqueous phase using isopropanol. RNA quantification was performed by photometric analysis. Total RNA (2 g) was then reverse transcribed using the first strand cDNA synthesis kit for RT-PCR (AMV; Roche Molecular Biochemicals, Indianapolis, Indiana, USA). The resulting CDNA was then used as a template for PCR. For Fas, we used primer pairs from R\&D System (RDP-59-025) and followed the manufacturer's instructions.

\section{Adenovirus preparation}

To generate high virus stocks, $2 \times 10^{8} 293$ packing cells at $90 \%$ confluence were infected at a multiplicity of infection of 5-10 PFU per cell. Infected cells were cultured for 3-5 days until a strong cytopathic effect could be observed and approximately $50 \%$ of the cells were detached. Cells were then collected by centrifugation, and viral particles were released by four cycles of freezing in liquid nitrogen and rapid thawing at $37^{\circ} \mathrm{C}$. For further purification, the virus preparation was subjected to twofold $\mathrm{CsCl}$ banding. $\mathrm{CsCl}$ banding and determination of infectivity by viral plaquing were performed according to standard protocols, as described previously. Endotoxin contamination was monitored by the LAL test kit (Chromogenix, Molndal, Sweden), following the manufacturer's protocol. All virus preparations used for infection experiments were LPS free. Virus preparations were stored at $-80^{\circ} \mathrm{C}$ in $25 \%$ glycerol, $10 \mathrm{mM}$ Tris $\mathrm{HCl}(\mathrm{pH} 7.4), 1 \mathrm{mM}$ $\mathrm{MgCl}_{2}$, and $140 \mathrm{mM} \mathrm{NaCl}$. The adenoviral vectors (adv) used

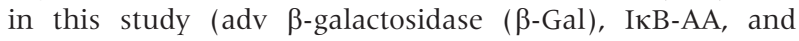
dominant negative Fas associated death domain (dnFADD)) have been described previously. ${ }^{22}$

\section{Hepatocyte isolation: cell cultures and infection experiments with adenovirus}

Anaesthetised mice were cannulated at the portal vein and the liver perfused with a $0.05 \%$ collagenase (Serva, Heidelberg, Germany) solution (3.9 g NaCl; $0.5 \mathrm{~g} \mathrm{KCl} ; 0.7 \mathrm{~g}$ $\mathrm{CaCl}_{2}$; HEPES $24 \mathrm{~g} / \mathrm{l}$ at $\mathrm{pH}$ 7.6). The obtained cell suspension was then passed through a sieve and centrifuged. Hepatocytes were plated on collagen coated petri dishes (collagen $\mathrm{R}$ solution $0.2 \mathrm{mg} / \mathrm{ml}$ in $0.1 \%$ acetic acid; Serva) and cultured overnight in supplemented Dulbecco's Eagle medium (+1\% glutamine; $1 \%$ Na pyruvate; $20 \mathrm{mM}$ HEPES; $0.05 \%$ insulin; 6-10 M lithocholic acid) with $10 \%$ fetal calf serum. The next day hepatocytes were challenged to undergo apoptosis after cross linking of the Fas receptor with a monoclonal antimouse Fas monoclonal antibody, clone Jo2 (2.5-10 $\mu \mathrm{g} / \mathrm{ml}$ per $2 \times 10^{6}$ hepatocytes) (Pharmingen, San Diego, California, USA). Negative controls (untreated hepatocytes) were incubated with medium alone. Hepatocytes were cultured for an additional 4-24 hours, as indicated. Cells were then washed in cold phosphate buffered saline (PBS) and resuspended in binding buffer. Cells $\left(10^{5}\right)$ were then incubated with annexin V-FITC and propidium iodide (PI) or annexin V or PI alone as controls, and then analysed within one hour by FACS analysis (annexin V-FITC apoptosis detection kit II; Pharmingen). Morphological changes typical of cell apoptosis, such as membrane blebbing and cell shrinkage, were visualised using an Olympus microscope B×63 (Olympus Optical Co., Hamburg, Germany).

In adenovirus studies using adv-dnFADD or $\operatorname{adv}-\mathrm{I} \kappa \mathrm{B} \alpha$, hepatocytes were infected with 100 PFU overnight. The next day, hepatocytes were washed twice in PBS and incubated for two hours either with medium containing anti-Fas antibody or with medium alone followed by apoptosis analysis in accordance with the manufacturer's instructions (annexin VFITC apoptosis detection kit II; Pharmingen). 
A

D

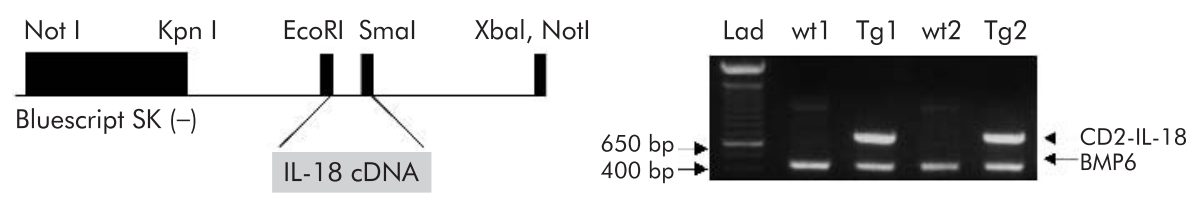

B

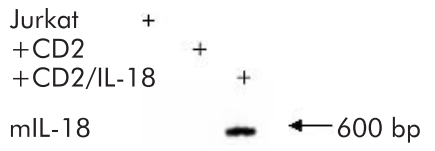

C
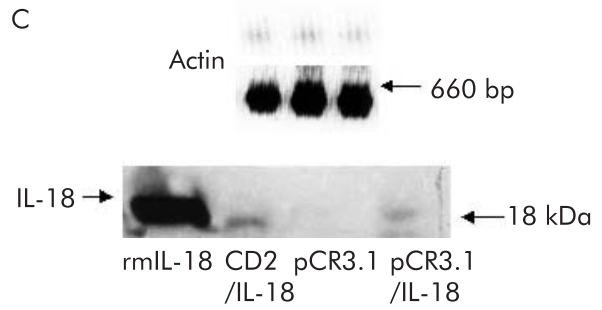

Figure 1 Design of the construct containing the human CD2 minigene and the mature mouse CDNA for interleukin 18 (CD2-IL-18) used to induce transgenic (Tg) IL-18 overexpression in FVB mice (A). This construct $(10 \mu \mathrm{g})$, or a construct containing the CD2 minigene alone, was transiently transfected into $2.5 \times 10^{7}$ Jurkat cells using the diethylaminoethyl-dextran method. Forty eight hours after cell transfection, proteins and RNA were analysed by western blot analysis (C) and reverse transcription-polymerase chain reaction (RT-PCR) (B). Similar data were seen in RAW264.7 cells (not shown). For detection of mature IL-18 protein $(18 \mathrm{kDa}), 75 \mathrm{ng}$ of recombinant murine IL-18 were used as a positive control. In vitro, mature IL-18 transcription and translation were detected only after transfection with the expression vector CD2/IL-18 but not with the empty control vector CD2. As a control, the original vector pCR3.1 and pCR3.1 with insertion of cDNA for IL-18 (pCR3.1/IL-18) were analysed. PCR was used to analyse transgenic integration in genomic DNA extracted from the ear or tail of IL-18 Tg mice (D) using upstream primers for CD2 and downstream primers for IL-18. The endogenous bone morphogenetic protein 6 gene (BMP6) was used as an internal control for PCR.

\section{In vivo infection experiments with adenoviruses expressing dnFADD and $I_{\kappa} B \alpha$}

IL-18 Tg mice were infected with $10^{10} \mathrm{PFU}$ of adenoviruses expressing dnFADD, I $\kappa \mathrm{B}$, or $\beta$-Gal intraperitoneally. Three days after infection, primary hepatocytes were isolated and cultured overnight on six well plates on collagen, as described above. At this time point, hepatocytes were recovered by scraping with a cell scraper, washed in PBS, and analysed by FACS analysis after staining with annexin V and PI, as specified above.

Isolation and purification of spleen mononuclear cells Spleen mononuclear cells were isolated from freshly obtained specimens from healthy FVB wild-type or IL-18 Tg mice. Erythrocytes were removed from spleen cell suspensions by hypotonic lysis in ammonium chloride and potassium chloride buffer. Cells were cultured in complete RPMI medium supplemented with $3 \mathrm{mM}$ L-glutamine, $10 \mathrm{mM}$ HEPES buffer, $100 \mathrm{U} / \mathrm{ml}$ penicillin-streptomycin, and $10 \%$ heat inactivated fetal calf serum in a humidified atmosphere with $5 \% \mathrm{CO}_{2}$ in a $37^{\circ} \mathrm{C}$ incubator in the presence or absence of hamster antibodies against mouse CD3 and CD28 (CD3 clone 1452C11 $2 \mathrm{~g} / \mathrm{ml}$; CD28 clone $37.510 .5 \mu \mathrm{g} / \mathrm{ml}$; Pharmingen), LPS $1 \mu \mathrm{g} / \mathrm{ml}$ (Sigma ), IFN- $\gamma(10 \mathrm{ng} / \mathrm{ml})$, and IL-12 (5 ng/ml).

\section{ELISA}

Concentrations of cytokines released in the cell culture supernatant and in serum were assessed by ELISA using R\&D Systems and Pharmingen antibodies and recombinant cytokines on 96 well plates (MaxiSorb; Nunc, Naperville, Illinois, USA), and performed in accordance with the manufacturer's instructions. IL-18 in cell culture supernatants and serum was detected and quantified using a specific sandwich ELISA (OptEIA system; BD Biosciences, San Diego, California, USA).

\section{Protein extraction and western blot analysis}

Tissue proteins were extracted as previously described. ${ }^{24}$ Briefly, tissue was homogenised in PBS using an electrical homogeniser and protein extracted in the presence of protease inhibitors (in $325 \mathrm{l} \mathrm{PBS}, 25 \mu \mathrm{l}$ aprotinin $(2.2 \mathrm{mg} /$ $\mathrm{ml}), 25 \mu \mathrm{l}$ trypsin inhibitor $(5 \mathrm{mg} / \mathrm{ml}), 25 \mu \mathrm{l} 10 \%$ Nonidet, $25 \mu \mathrm{l}$ sterile water). Protein concentrations were determined by spectrophotometry with a BioRad protein assay (Bradfords' method) (BioRad Laboratories, Munchen, Germany). The standard curve was performed using $0,2,4,8$, and $16 \mathrm{~g}$ of bovine serum albumin $/ \mathrm{ml}$. Nuclear and cytoplasmic proteins were extracted from primary hepatocytes as follows: the cell pellet was washed with cold PBS twice followed by a 10 minute incubation period in buffer A (10 mM HEPES; $1.5 \mathrm{mM} \mathrm{MgCl}_{2} ; 10 \mathrm{mM} \mathrm{KCl}$; PMSF $0.5 \mathrm{mM}$ ) with $0.4 \% \mathrm{NP} 40$ on ice. After centrifugation, supernatants containing the cytoplasmic proteins were frozen and the pellet was incubated with buffer B (20 mM HEPES; $0.42 \mathrm{M} \mathrm{NaCl} ; 1.5 \mathrm{mM}$ $\mathrm{MgCl}_{2} ; 0.2 \mathrm{mM}$ EDTA; PMSF $0.5 \mathrm{mM}$, and DTT $1 \mathrm{mM}$ ) to extract nuclear proteins. Equal amounts of protein extract were added to the electrophoresis sample buffer $(5 \times)$. After boiling, proteins were separated by $10 \%$ or $15 \%$ sodium dodecyl sulphate-polyacrylamide gel electrophoresis, transferred to nitrocellulose membranes, and detected with a specific antibody against nuclear factor $\kappa \mathrm{B}$ (NF $\kappa \mathrm{B})$ p65 (1:200) (Santa Cruz, Heidelberg, Germany), polyclonal goat antimouse IL-18 (R\&D System), caspase 8 and anti-FasL (Santa Cruz), monoclonal rat antimouse IL-18 (1:500) (R\&D), AKT-P (Cell Signaling Technology, New England Biolabs, Frankfurt, Germany), and anti-Fas receptor (Transduction Laboratories, Pharmingen, Germany) at the final concentration suggested by the manufacturers. Specific binding were visualised with the ECL western blotting analysis system after a one hour incubation period with a horseradish peroxidase labelled secondary antibody (Amersham, Germany). 


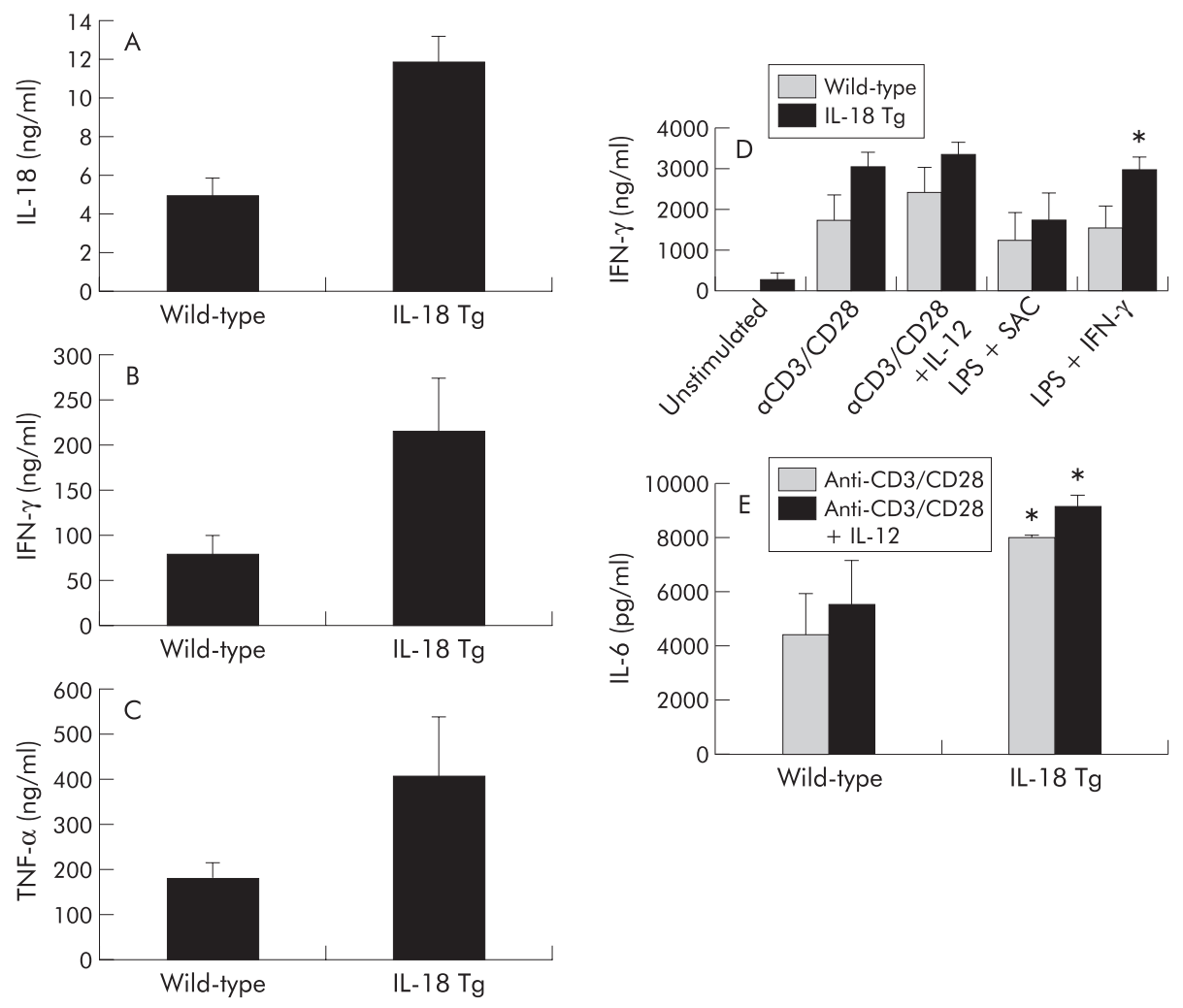

Figure 2 Cytokine expression in the serum of interleukin 18 transgenic (IL-18 Tg) mice. Serum levels of IL-18 in transgenic mice $(n=6)$ and wild-type littermates were measured using a mIL-18 ELISA kit (A). Interferon $\gamma$ (IFN- $\gamma$ ) and tumour necrosis factor $\alpha$ (TNF- $\alpha$ ) were measured using commercially available kits (B and C, respectively). Cytokines released after 48 hours in the supernatants of splenocytes isolated from wild-type and IL-18 Tg mice are shown. IFN- $\gamma$ production was significantly increased in IL-18 Tg cells after lipopolysaccharide (LPS) plus IFN- $\gamma$ challenge (D) whereas IL- 6 was increased after stimuli that preferentially induced T cell activation (E). SAC, Staphylococcus aureus Cowan's antigen.

\section{Splenocyte isolation and adoptive transfer of $\mathrm{CD} 6 \mathrm{~L}^{+}$} CD4 ${ }^{+} \mathrm{T}$ cells in SCID mice

Splenocytes were isolated from wild-type and IL-18 Tg mice by standard methods and in some experiments cultured with antibodies to $\mathrm{CD} 3$ and $\mathrm{CD} 28$. For the adoptive transfer experiments, $\mathrm{CD}^{+} \mathrm{T}$ cells were directly purified from isolated spleen mononuclear cells, from both wild-type and transgenic IL-18 FVB mice using FITC conjugated monoclonal antibodies (Pharmingen) and anti-FITC immunomagnetic microbeads in a multiparameter magnetic sorter system (MACS; Miltenyi; Bergisch Gladbach, Germany). The resulting $\mathrm{CD}^{+}$cells (purity 97\%) were further separated by immunomagnetic microbeads into $\mathrm{CD}_{2} \mathrm{~L}^{+}$and $\mathrm{CD}^{-} \mathrm{L}^{-} \mathrm{T}$ cells. The former cells showed high expression of CD45RB by FACS analysis. Finally $1 \times 10^{6} \mathrm{CD}_{2} \mathrm{~L}^{+} /\left(\mathrm{CD} 45 \mathrm{RB}^{\text {high }}\right) \mathrm{CD}^{+} \mathrm{T}$ cells were transferred intraperitoneally into CB17 SCID mice (Charles River Laboratories, Wilmington, Massachusetts, USA). Reconstituted SCID mice were maintained in isolated ventilated cages for the indicated times and monitored by body weight curves and histological analysis of the liver.

\section{Macroscopic analysis, determination of liver weight, and blood analysis}

Organs of transgenic mice from each founder were macroscopically compared with wild-type control mice. The weight of the different organs was then corrected for total body weight. The results are reported as the ratio of the organ weight and total body weight multiplied by 100 . Blood samples were taken after ventricular puncture from IL-18 Tg and wild-type control mice. For serum cytokine analysis, blood was coagulated at $4^{\circ} \mathrm{C}$ for three hours and then centrifuged at $3000 \mathrm{rpm}$ for 10 minutes. The supernatant (serum) was frozen, and subsequently serum cytokine content was quantified after ELISA immunoassay, as described below.
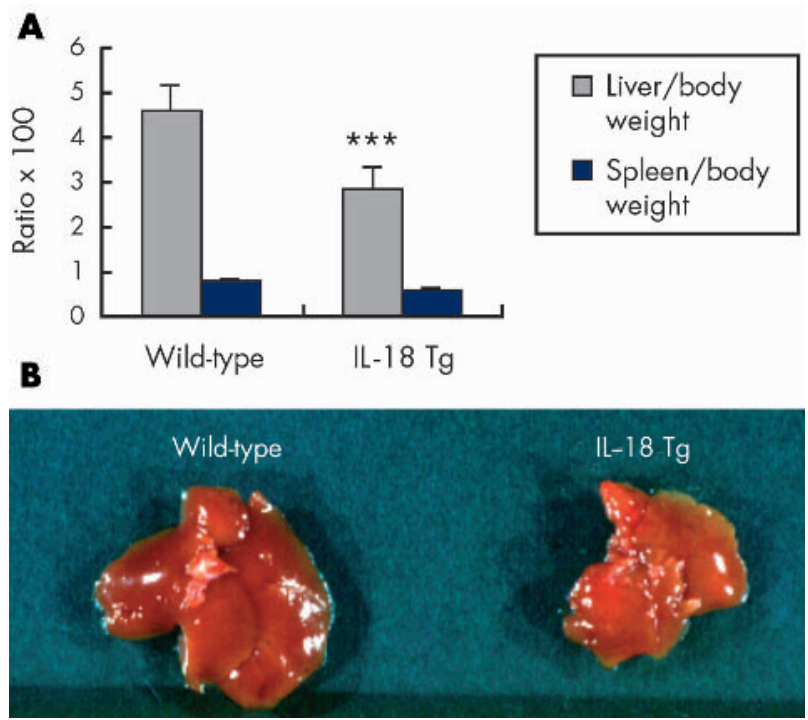

Figure 3 Liver injury in interleukin 18 transgenic (IL-18 Tg) mice. Liver weight from IL-18 Tg and wild-type mice was related to total body weight and this ratio was multiplied by 100 (A). ${ }^{* * *}$ Significant difference compared with wild-type littermates. The size of the liver of IL-18 Tg mice was reduced compared with that of wild-type littermates (B). 

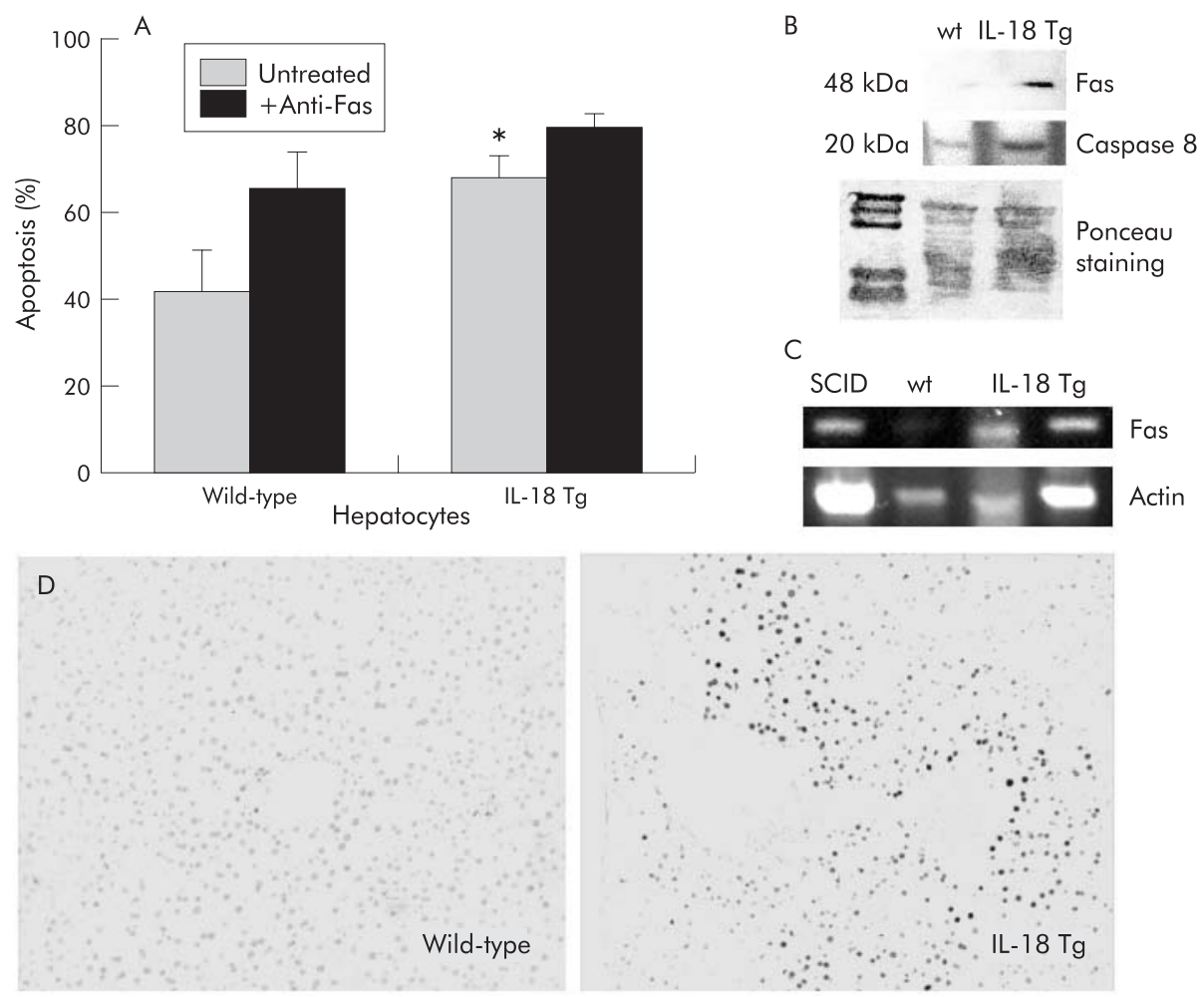

Figure 4 Hepatocytes isolated from interleukin 18 transgenic (IL-18 Tg) mice exhibited increased spontaneous and Fas mediated apoptosis. Apoptosis in primary hepatocytes was analysed by the annexin $\mathrm{V}$ and propidium iodide (PI) method (A). Hepatocytes isolated from IL-18 Tg mice and cultured for 24 hours exhibited increased late apoptosis (annexin $\mathrm{V}$ and PI high positive) compared with hepatocytes isolated from wild-type mice ( $\left.n=5 ;{ }^{*} \mathrm{p}<0.05\right)$. Cross linking of Fas with an antibody directed against Fas (10 $\mu \mathrm{g} / 10^{7}$ cells) further induced apoptosis in wild-type mice (A). (B) The livers of IL-18 Tg mice expressed increased amounts of Fas and caspase 8 protein ( $\mathrm{B}$; western blot analysis) and Fas RNA (C; polymerase chain reaction analysis) compared with that of wild-type littermates. Ponceau staining showed equal loading. In addition, we found that the liver of SCID mice expressed Fas (C). (D) In situ apoptosis in the liver of IL-18 Tg and wild-type mice was assessed using the TUNEL reaction. Representative views are shown. Increased numbers of apoptotic hepatocytes were detected using a Zeiss Axioskop mot plus microscope (magnification 200 $\times$ ).

\section{Histological analysis of liver cross sections}

Tissues were removed, fixed in 10\% buffered formalin, mounted in paraffin, sectioned, and stained with haematoxylin-eosin. Pathological evaluation was performed in a blinded fashion by the same pathologist (HAL).

\section{Analysis of cell apoptosis in liver specimens}

Paraffin sections of liver derived from both IL-18 Tg and wild-type mice as well as from SCID reconstituted mice were analysed for apoptosis by terminal deoxynucleotidyltransferase (TdT) treatment that induces incorporation of FITC labelled deoxynucleotides to DNA strand breaks in situ (TUNEL; TdT mediated fluorescein dUTP nick end labelling technique) (in situ cell death detection kit, fluorescein; Roche Molecular Biochemicals). Nuclei were counterstained with DAPI staining (Vector Laboratories, Linaris GmbH, Wertheim, Germany) and analysed by a fluorescence microscope (Olympus Optical Co, Hamburg, Germany). In some experiments, as shown in fig 4D, we detected in situ apoptosis in the liver using the II. ApopTag Peroxidase Kit (Intergen, New York, USA) in accordance with the manufacturer's instructions.

\section{Statistical analysis}

The Student's $t$ test was used for data analysis. Data are expressed as mean (SEM).

\section{RESULTS}

\section{Generation of IL- 18 transgenic mice}

To obtain insight into the functional immunoregulatory role of IL-18 in vivo, we generated IL-18 transgenic mice.
Accordingly, we amplified the murine IL-18 coding region by PCR using RNA from LPS plus SAC stimulated RAW264.7 monocytes and subcloned the IL-18 cDNA (595 bp) into an expression cassette driven by the human CD2 promoter/ enhancer using blunt end ligation yielding the CD2-mIL-18 expression vector (fig lA). This expression construct was then transiently transfected into Jurkat T cells. Mature IL-18 ( $18 \mathrm{kDa}$ ) was detected by western blot analysis in the cell lysate of Jurkat cells transfected with the CD2-mIL-18 construct but not in control $\mathrm{T}$ cells transfected with the CD2 vector, suggesting that the vector can express mIL-18 (fig 1C). Consistently, mIL-18 mRNA was detected by RT-PCR (fig 1B) in Jurkat cells transfected with the CD2IL18 vector but not in cells transfected with the empty CD2 expression cassette.

The CD2-mIL-18 construct was then digested with the restriction enzymes $\mathrm{KpnI}$ and NotI and the resulting fragment containing the IL-18 expression cassette was microinjected into the pronuclei of fertilised eggs of FVB/NHSD mice, resulting in the generation of two independent founder lines that showed transgene integration and the same phenotype described below. Transgene integration was confirmed by PCR using simultaneously CD2-IL-18 transgene specific primers that resulted in a $650 \mathrm{bp}$ fragment in transgenic mice and primers to detect BMP6 as the internal control (fig 1D).

\section{Transgenic IL- 18 mice exhibit increased IFN- $\gamma$ and TNF- $\alpha$ levels in serum}

To confirm overexpression of mature IL-18 in transgenic mice derived from the two cell lines, we measured IL-18 protein 
levels in the serum of these mice by ELISA. As shown in fig 2A, IL-18 transgenic mice showed significantly increased mature IL-18 in serum compared with control littermates $(p=0.01)$. In addition, levels of both IFN- $\gamma$ and TNF- $\alpha$ were increased in the serum of IL-18 transgenic mice when compared with control mice (fig $2 \mathrm{~B}$ and $2 \mathrm{C}$, respectively). In contrast, serum levels of IL-4 and IL-6 remained unchanged in IL-18 transgenic mice, suggesting a selective effect of IL-18 overexpression on cytokine production in vivo (data not shown). In addition, splenocytes isolated from IL-18 Tg mice released increased amounts of IL-6 after T cell specific immunological stimuli (anti-CD3/anti-CD28 or anti-CD3/anti-CD28 plus IL-12) (fig 2E). These cells also produced significantly increased amounts of IFN- $\gamma$ when challenged with LPS plus IFN- $\gamma$ (fig 2D).

\section{The liver of IL- 18 transgenic mice is reduced in size and weight}

IL-18 was originally identified in extracts of mice treated with $P$ acnes plus LPS and appears to control liver injury induced by $P$ acnes plus LPS. In addition, IL-18 knockout mice are resistant to LPS induced liver injury. ${ }^{10}$ Therefore, we analysed the effect of overexpression of IL-18 on the liver in vivo. Macroscopic analysis of the liver showed that transgenic IL-18 mice had a lighter and smaller liver and a reduced liver/ body weight ratio compared with wild-type littermates $(\mathrm{p}=0.0003)($ fig $3 \mathrm{~A}, \mathrm{~B})$.

\section{Hepatocytes isolated from IL- 18 transgenic mice exhibit increased Fas mediated apoptosis}

To investigate whether the observed liver weight reduction in IL-18 transgenic mice was due to increased necrosis or apoptosis of liver cells, we first performed TUNEL assays in the liver of both wild-type and IL-18 Tg mice and found increased apoptotic hepatocytes in the liver of IL-18 Tg mice, indicating that loss of liver weight was due to increased apoptosis of hepatocytes in IL-18 Tg mice (fig 4D). We then isolated and cultured hepatocytes from the liver of both IL-18 Tg mice and wild-type littermates, as specified in the materials and methods sections. After 4 and 24 hours of cell culture, we analysed the apoptosis rate by the annexin V and PI method and found that hepatocytes isolated from IL-18 Tg mice exhibited an increased spontaneous apoptosis rate compared with wild-type littermates $(\mathrm{n}=5)$ (fig 4A).

In an attempt to identify the mechanism of apoptosis in hepatocytes derived from IL-18 Tg mice, we cross linked the Fas receptor on the surface of hepatocytes with an antibody. Cross linking of Fas receptor on hepatocytes derived from wild-type mice induced a significant increase in hepatocyte apoptosis (fig 4A) and had less effect on the apoptosis rate of hepatocytes derived from IL-18 Tg mice, suggesting spontaneous activation of the Fas pathway in the latter mice in vivo (fig 4A).

To establish the validity of the paradigm that cell death in IL-18 Tg hepatocytes is Fas mediated, we next analysed Fas expression in the liver of both wild-type and IL-18 Tg mice and found that the livers from IL-18 Tg mice contained increased amounts of Fas protein and caspase 8 (fig 4B, 4C). We then infected IL-18 Tg mice with an adenovirus overexpressing the dominant negative Fas associated death domain (adv-dnFADD) protein with the aim of blocking Fas signal transduction in vivo. As shown in table 1 , in vivo blockade of Fas led to a significant decrease in hepatocyte cell death (from $67.33 \%$ to $29.90 \%$ ) whereas expression of IкB had little effect. These results are consistent with direct in vivo involvement of the Fas receptor in mediating cell death of IL-18 Tg hepatocytes.
Increased translocation of NFKB into the nucleus in hepatocytes isolated from IL-18 transgenic mice

To investigate whether expression and activation of NFKB is regulated by Fas pathway activation in IL-18 Tg mice, we analysed cytoplasmic and nuclear NFKB protein before and after Fas cross linking in hepatocyte cultures from wild-type and IL-18 Tg mice. Hepatocytes derived from wild-type mice showed, after Fas cross linking, increased expression of NFKB p65 accompanied by its translocation into the nucleus. In contrast, in hepatocytes derived from IL-18-Tg mice, NFкB p65 was already spontaneously expressed at high levels and translocated into the nucleus (fig 5A). These results suggest that Fas mediated apoptosis in wild-type hepatocytes is accompanied by increased activation of NFKB in hepatocytes derived from wild-type mice whereas hepatocytes from IL-18 $\mathrm{Tg}$ mice exhibited evidence of spontaneous activation of the NFкB pathway.

\section{Role of NF $\mathrm{B}$ in Fas activated cell death}

In vivo blockade of NFKB by infection of transgenic mice with an adenovirus overexpressing IкB caused no change in hepatocyte apoptosis (table 1 ). In addition, in vitro infection of IL-18 Tg hepatocytes with this adenovirus ( $\operatorname{adv}-\mathrm{IkB} \alpha)$ and cross linking of the Fas receptor with an anti-Fas antibody also did not lead to modification of hepatocyte apoptosis (table 2) although these cells exhibited decreased nuclear levels of NFKB and unchanged levels of FasL (fig 5B). Consistent with these findings, phosphorylated Akt, a prosurvival marker, was found to be decreased after hepatocyte infection with $\operatorname{adv}-\operatorname{IkB} \alpha$, suggesting an antirather than a proapoptotic role of NFKB in hepatocytes from IL-18 transgenic mice (fig 5B).

\section{Reconstitution of SCID mice with CD62 $\mathrm{L}^{\text {high }} \mathrm{T}$ cells derived from IL- 18 transgenic mice leads to severe liver injury}

To investigate whether apoptosis of hepatocytes in IL-18 Tg could be adoptively transferred by IL-18 producing cells, we purified $\mathrm{CD}_{2} \mathrm{~L}^{+}$(L-selectin) ${ }^{\text {high }} \mathrm{T}$ cells from the spleen of IL-18 Tg and wild-type mice to reconstitute SCID mice that expressed detectable levels of Fas in hepatocytes (fig 4C). The body weight of reconstituted SCID mice was monitored every week after cell transfer. Five to six weeks after cell transfer, mice receiving transgenic cells were sacrificed because they had lost more than $20 \%$ of their initial body weight and some had died. SCID mice reconstituted with cells derived from IL-18 Tg mice showed elevated levels of serum IL-18 and IFN$\gamma$ compared with SCID mice that had been reconstituted with naïve lymphocytes derived from wild-type control littermates (fig 6H). No evidence of colitis was seen. Moreover, the liver of SCID mice reconstituted with cells derived from wild-type mice had a normal architecture with well demarcated portal areas without evidence of tissue injury with normal bile canaliculi. In contrast, the liver isolated from SCID mice that had been reconstituted with cells derived from IL-18 Tg mice had massive periportal fibrosis and inflammation, with extensive disseminated and confluent periportal parenchymal destruction, both in the form of apoptotic bodies and of neutrophil associated piecemeal necrosis (fig 6A-D). The TUNEL reaction on liver sections of reconstituted SCID mice demonstrated many positive hepatocytes in SCID mice which had been reconstituted with cells derived from IL-18 Tg mice (fig 6F,G). Such apoptotic bodies were absent in SCID mice that had been reconstituted with cells derived from wild-type mice (fig 6E).

\section{DISCUSSION}

We have reported here that transgenic expression of IL-18 under a CD2 promoter/enhancer construct induces hepatocyte 
Table 1 Blockade of Fas signal transduction in vivo reduces hepatocyte apoptosis in interleukin 18 transgenic (IL-18 Tg) mice

\begin{tabular}{|c|c|c|c|}
\hline Hepatocytes IL-18 Tg & $+\beta-G a l$ & + Adv-dnFADD & $+\mathrm{Adv}-\mathrm{IkB} \alpha$ \\
\hline Annexin ${ }^{\text {high }} /\left.\mathrm{Pl}\right|^{\text {high }}$ & $67.33(5.3)$ & $29.90(3.18)$ & $65.27(27.45)$ \\
\hline \multicolumn{4}{|c|}{$\begin{array}{l}\text { IL-18 Tg mice were infected with } 10^{10} \mathrm{PFU} \text { of adenoviruses (Adv) expressing dominant negative Fas associated } \\
\text { death domain (dnFADD), I } \kappa \text { B, or } \beta \text {-galactosidase ( } \beta \text {-Gal) intraperitoneally for three days followed by analysis of } \\
\text { hepatocyte apoptosis by annexin V/propidium iodide (PI) staining by FACS. } \\
\text { Results are reported as per cent of apoptotic cells. }\end{array}$} \\
\hline
\end{tabular}

apoptosis with consequent reduction of liver size and weight. Hepatocyte apoptosis was at least partially dependent on the Fas pathway, as demonstrated by increased Fas expression in hepatocytes derived from IL-18 transgenic mice and by experiments involving Fas cross linking on isolated hepatocytes. Moreover, in vivo infection with an adenovirus overexpressing the dominant negative form of FADD markedly reduced hepatocyte cell death in IL-18 Tg mice. Although NFкB p65 was spontaneously activated in IL-18 Tg hepatocytes, it did not contribute to induction of hepatocyte apoptosis, as demonstrated by the lack of changes in hepatocyte apoptosis on adenoviral overexpression of I $\mathrm{KB}$. In addition, in vivo overexpression of $\mathrm{I} \kappa \mathrm{B} \alpha$ after adenovirus infection did not lead to changes in hepatocyte apoptosis in IL-18 Tg mice. Liver injury could be adoptively transferred by splenic $\mathrm{T}$ cells from IL-18 Tg spleen into SCID mice, resulting in severe liver failure with massive periportal fibrosis and inflammation associated with hepatocyte apoptosis. In summary, IL-18 Tg mice provide a novel tool to study mechanisms of IL-18 dependent liver injury in vivo.

Compared with peripheral lymphoid organs, the liver has a unique anatomical environment that is closely associated with its immunological function. In addition to the presence of large quantities of resident Kupffer cells, the liver contains conventional $\mathrm{T}$ cells, NK cells, and NK-T cells at high frequency. Liver NK cells and NK1.1 T cells exhibit cytotoxicity against virus infected hepatocytes or tumour cells via CD95(Fas), TNF, or perforin dependent pathways. ${ }^{25}{ }^{26}$ Interestingly, a new cytokine, denoted IL-18, has been identified that modulates the cytotoxicity of these cells. IL-18 is produced by Kupffer cells and has been shown to be a potent inducer of IFN- $\gamma$ production by T cells and NK cells and acts as a costimulatory factor for T cell activation. ${ }^{27-29}$ In addition, IL-18 augments NK cell activity in the spleen and liver, as well as cytotoxicity of $\mathrm{T}$ helper 1 cells, probably through an increase in FasL expression, suggesting that its role may be to regulate cytotoxicity against tumours and microbes or virus infected cells. To address the role of IL- 18 in the liver under in vivo conditions, in the present study we generated IL-18 Tg mice under the control of the CD2 promoter/enhancer construct. These mice expressed increased mature IL-18 both in serum and in the liver, as demonstrated by ELISA and western blot analysis. Furthermore, augmented IFN- $\gamma$ release by splenocytes from transgenic mice was found after stimuli that have been shown to induce IL-18 production, such as LPS stimulation. In addition, splenocytes isolated from IL-18 Tg mice and challenged with CD4-T cell specific stimuli (such as anti-CD3/ anti-CD28), released increased IL-6 in the supernatant, a cytokine known to be involved in liver regeneration. ${ }^{30}$

IL-18 Tg mice exhibited a significant reduction in liver size and weight. Primary hepatocytes isolated from IL-18 Tg mice showed augmented Fas expression and exhibited increased ongoing apoptosis compared with wild-type control mice, suggesting increased spontaneous apoptosis in the former compared with the latter. To understand the mechanism underlying the increased hepatocyte apoptosis in IL-18 Tg mice, we cross linked Fas receptor at the cell surface of freshly isolated hepatocytes and analysed cell apoptosis. In vitro cross linking of the Fas receptor increased significantly the apoptosis rate and induced translocation of NFKB into the nucleus in wild-type hepatocytes. In contrast, little or no further increase in the apoptosis rate was detected on Fas

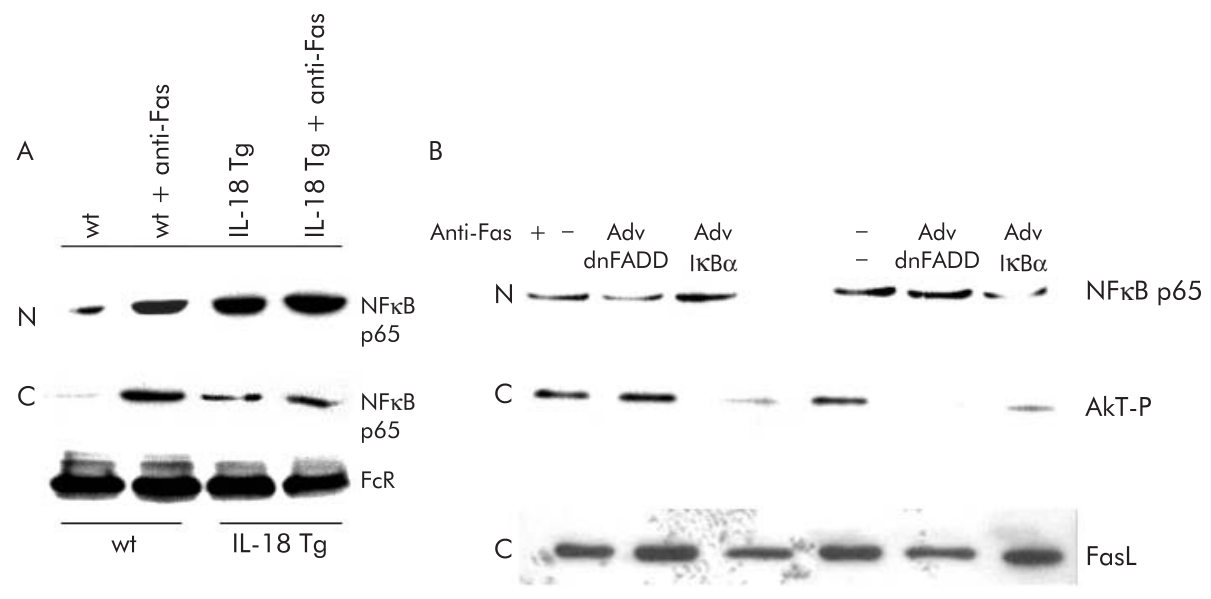

Figure 5 Spontaneous nuclear translocation of nuclear factor $\kappa B(N F K B)$ in hepatocytes isolated from interleukin 18 transgenic (IL-18 Tg) mice (A) and decreased activation of $N F \kappa B$ p 65 in hepatocytes isolated from IL-18 Tg mice infected with an adenovirus expressing $I_{\kappa} B \alpha(A d v \mid \kappa B \alpha)(B)$. Cytoplasmic (C) and nuclear (N) proteins from both IL-18 Tg and wild-type (wt) hepatocytes four hours after cell culture were analysed by western blot analysis for NFKB p65 expression (B). Western blot analysis of nuclear (N) and cytoplasmic (C) proteins isolated from primary hepatocytes isolated from either wild-type or IL-18 Tg mice treated with medium alone or with adenovirus (Adv) expressing dominant negative Fas associated death domain (dnFADD) or $I_{K} B \alpha$ and cross linked at the Fas receptor (B). Activation of the antiapoptotic protein AKT (Phospho-AKT:AkT-P) was decreased after infection with $a d v-I_{\kappa} B \alpha$ that caused inactivation of $N F \kappa B$. There were no changes in Fas ligand (FasL) expression. 
Table 2 Blockade of nuclear factor $\kappa \mathrm{B}$ activation by infection with adv- $\mathrm{I}_{\kappa} \mathrm{B} \alpha$ does not increase hepatocyte apoptosis

\begin{tabular}{|c|c|c|c|c|c|c|}
\hline & Wild-type & $\begin{array}{l}\text { Wild-type } \\
\text { Anti-fas }\end{array}$ & $\begin{array}{l}\text { Wild-type } \\
\text { AntiFas+adv-IкBa }\end{array}$ & IL-18 Tg & $\begin{array}{l}\text { IL-18 Tg } \\
\text { Anti-Fas }\end{array}$ & $\begin{array}{l}\text { IL-18 Tg } \\
\text { Anti-Fas+adv-IKB } \alpha\end{array}$ \\
\hline $\begin{array}{l}\text { Experiment } 1 \\
\text { Experiment } 2 \\
\text { Annexin } \mathrm{V}^{+} / \mathrm{Pl}^{+}\end{array}$ & 35.69 & $\begin{array}{l}54 \\
35.69\end{array}$ & $\begin{array}{l}49.38 \\
40.45\end{array}$ & 75.25 & $\begin{array}{l}75 \\
75.25\end{array}$ & $\begin{array}{l}72.37 \\
74.93\end{array}$ \\
\hline $\begin{array}{l}\text { Experiment } 1 \\
\text { Experiment } 2 \\
\text { Annexin } \mathrm{V}^{+} / \mathrm{Pl}^{-}\end{array}$ & 16.95 & $\begin{array}{l}29.97 \\
16\end{array}$ & $\begin{array}{l}33.06 \\
24.10\end{array}$ & 12.24 & $\begin{array}{l}14.39 \\
12.5\end{array}$ & $\begin{array}{l}16.85 \\
11.5\end{array}$ \\
\hline
\end{tabular}

Hepatocytes from wild-type and interleukin 18 transgenic (IL-18 Tg) mice were isolated followed by Fas cross linking and adenoviral (adv) gene transfer of I $\mathrm{KB}$, as indicated. Annexin V/propidium iodide (PI) staining was performed, as described in the methods section.

Results from two representative experiments are reported as per cent of apoptotic cells.

cross linking in hepatocytes derived from IL-18 Tg mice (without changes in NF $\kappa \mathrm{B}$ p65 activation), suggesting preactivation of the Fas pathway in these mice in vivo. In addition, FasL, which is expressed on the surface of hepatocytes, was not further increased on primary hepatocytes derived from IL-18 Tg mice, suggesting that IL-18 might induce in vivo FasL expression in $\mathrm{T}$ cells $^{31-33}$ but not hepatocytes.

It has been reported that on IL- 18 stimulation, $\operatorname{IkB} \alpha$ is degraded and NFKB translocates to the nucleus, suggesting a key role for IL-18 in mediating NFאB activation. ${ }^{34}{ }^{35}$ Indeed, we observed constitutive NFאB activation in hepatocytes from IL-18 transgenic mice, indicating an important role for IL-18 in inducing NFKB activation in vivo. The link between Fas and NFKB activation was then investigated with and without Fas receptor cross linking and simultaneous infection of hepatocytes with an adenovirus overexpressing

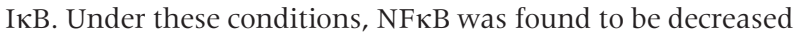
in the nucleus of infected hepatocytes, and AKT phosphorylation, a marker of cell survival, ${ }^{36}{ }^{37}$ was downregulated while FasL and the apoptosis rate remained unchanged, suggesting an antiapoptotic rather than a proapoptotic role for NFKB in hepatocytes isolated from IL-18 Tg mice. These results were also supported by another cohort of experiments where overexpression in vivo of I $\mathrm{kb} \alpha$ with an adenovirus in IL-18 Tg mice for three days did not affect hepatocyte apoptosis of infected mice. These findings are also consistent with the observation that RelA-/- mice die at embryonic day 15 as a result of extensive liver apoptosis. ${ }^{38}$

In summary, our data indicate that IL-18 is a critical cytokine for the regulation of hepatocyte apoptosis via a Fas dependent mechanism in vivo. The fact that liver injury induced by hepatocyte apoptosis could be adoptively transferred by $\mathrm{T}$ cells from transgenic mice to SCID mice suggests that both the lymphoid component and hepatocytes are required for IL-18 induced liver alterations. In fact, as IL-18 is well known to induce FasL expression on $\mathrm{NK}$ and $\mathrm{CD}^{+} \mathrm{T}$ cells ${ }^{27}$ and IL-18 overexpression led to increased expression of Fas on hepatocytes, our data are consistent with a model where Fas/FasL interactions on $\mathrm{T}$ cells and hepatocytes induce liver injury in vivo. In addition, expression of both FasL and Fas on hepatocytes derived from IL-18 Tg mice suggests the potential
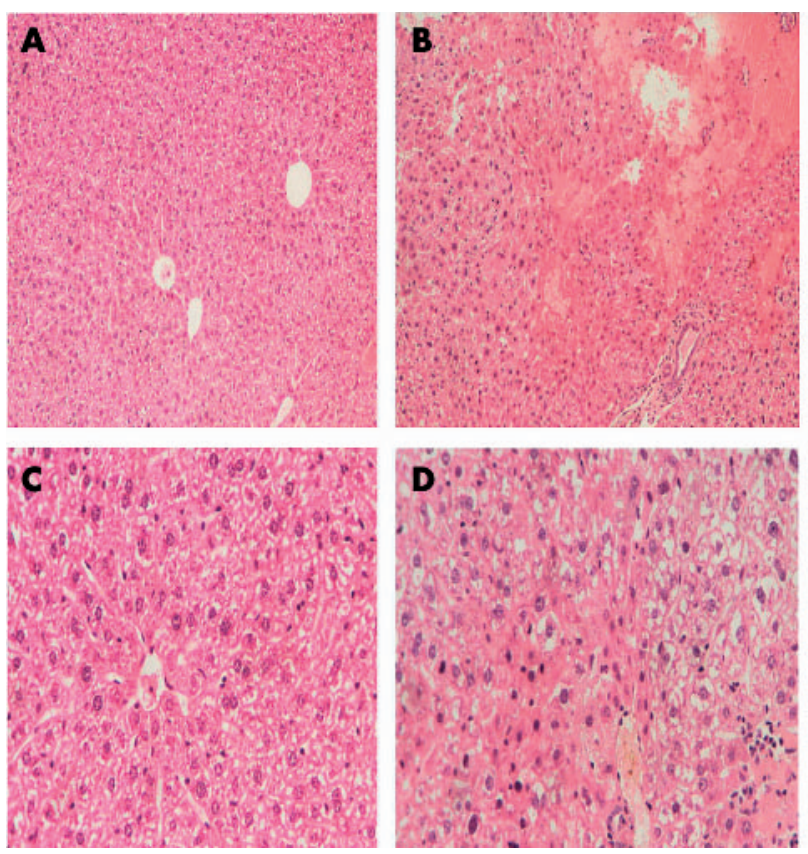
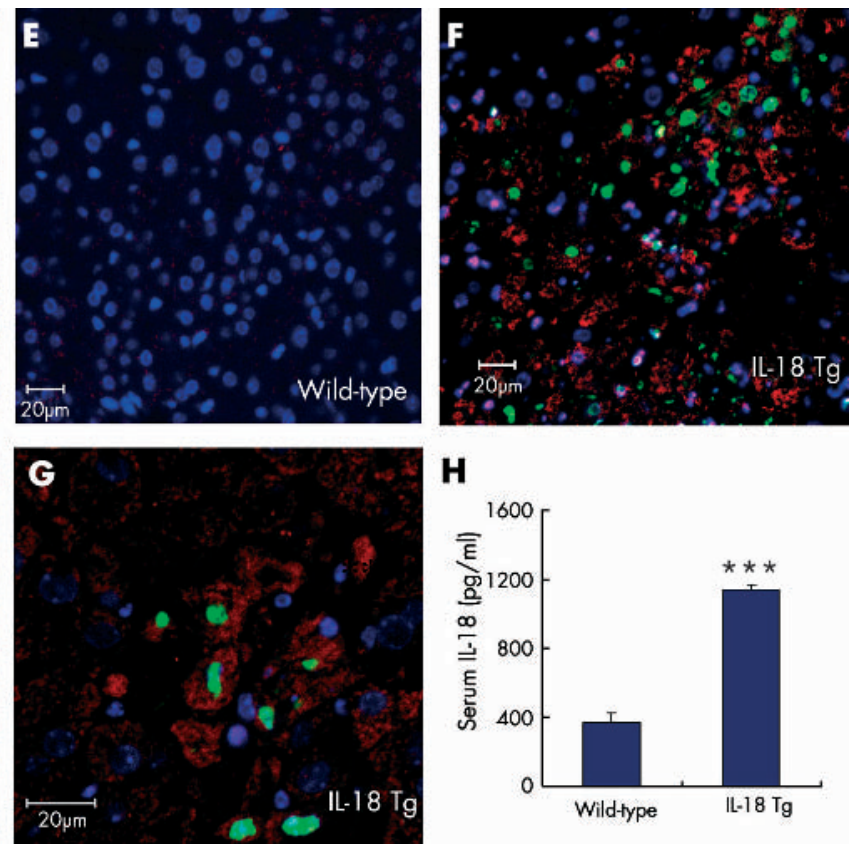

H

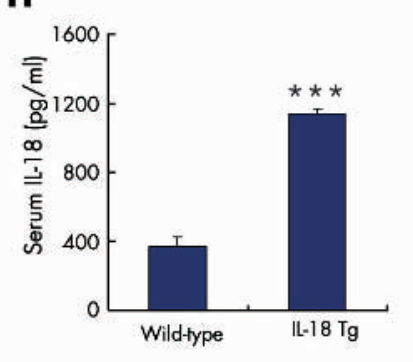

Figure 6 Reconstitution of SCID mice with T cells from interleukin 18 transgenic (IL-18 Tg) mice induced hepatocytes apoptosis. SCID mice reconstituted with spleen T cells derived from IL-18 Tg mice showed increased IL-18 in the serum, as shown by ELISA (H; $\left.{ }^{* *} p<0.01\right)$. Paraffin liver sections of SCID mice reconstituted with T cells from wild-type (A, C) and IL-18 Tg (B, D) mice stained with haematoxylin-eosin. The latter livers showed increased periportal fibrosis and inflammation, and apoptosis, as shown after the TUNEL reaction in green $(F, G)$. For comparison, a liver section from SCID mice reconstituted with CD62L positive cells derived from wild-type mice after the TUNEL reaction are shown (E). Nuclei were counterstained in blue with DAPI. IL-18 positive cells are shown in red. Magnification: $20 \times(A, C) ; 40 \times(B, D)$. 
activation of autocrine-paracrine mechanisms of apoptosis in the hepatocytes of these mice, as previously described for liver and biliary cells. ${ }^{39-41}$ Finally, modulation of NFKB activity in IL-18 Tg mice may allow other transcription factors to facilitate Fas mediated apoptosis. In any case, our data suggest a pivotal role for IL-18 in regulating hepatocyte apoptosis and liver injury in vivo via a Fas dependent pathway. These data are consistent with the recent demonstration of high IL-18 levels in the liver of patients with fulminant hepatic failure ${ }^{30} 42$ and suggest that overexpression of IL-18 may cause substantial liver injury in vivo.

\section{ACKNOWLEDGEMENTS}

SF and MFN are supported by a DGF and SFB548 grant. MP is supported by the Boehringer Ingelheim Fondation and $\mathrm{MH}$ is supported by a DFG fellowship.

\section{Authors' affiliations}

\section{S Finotto, J Siebler, M Hausding, M Schipp, S Wirtz, S Klein,} M Protschka, A Doganci, D Strand, A Lohse, P R Galle, M F Neurath, Laboratory of Immunology, I Medical Clinic, University of Mainz, Germany

H A Lehr, Laboratory of Immunology, I Medical Clinic, University of Mainz, Germany, and Institute of Pathology, Johannes GutembergUniversity of Mainz, Germany

C Trautwein, Department of Gastroenterology, Medizinische Hochschule, University of Hannover, Germany

R Khosravi-Fahr, Beth Israel, Deaconess Medical Center, Division of Pathology, Harvard Medical School, Boston, Massachusetts, USA M Blessing, Laboratory of Immunology, I Medical Clinic, University of Mainz, Germany and Centre for Biotechnology and Biomedicine, Faculty of Veterinary Medicine, University of Leipzig, Leipzig, Germany

\section{REFERENCES}

1 Okamura H, Tsutsui $\mathrm{H}$, Komatsu $\mathrm{T}$, et al. Cloning a new cytokine that induces IFN- $\gamma$ production by T-cells. Nature 1995;378:88-91.

2 Okamura H, Kashiwamura S-I, Tsutsui $\mathrm{H}$, et al. Regulation of interferongamma production by IL-12 and IL-18. Curr Opin Immunol 1998;10:259-64.

3 Dinarello CA. IL-18: a $\mathrm{T}_{\mathrm{H}}$ 1-inducing pro-inflammatory cytokine and new member of the IL-1 family. J Allergy Clin Immunol 1999;103:11.

4 McInnes IB, Gracie JA, Leung BP, et al. Interleukin 18: a pleiotropic participant in chronic inflammation. Immunol Today 2000;21:312.

5 Tsutsui H, Matsui K, Kawada Y, et al. IL-18 accounts for both TNF- $\alpha$ and Fas ligand-mediated hepatotoxic pathways in endotoxin induced liver injury in mice. J Immunol 1997; 159:3691.

6 Gu Y, Kuida K, Tsutsui $\mathrm{H}$, et al. Activation of interferon gamma inducing factor mediated by interleukin-1 $\beta$ converting enzyme. Science 1997; 275:206.

7 Yoshimoto T, Takeda K, Tanaka T, et al. IL-12 up-regulates IL-18R expression on T cells, Th1 cells and B cells: synergism with IL-18 for IFN-gamma production. J Immunol 1998;161:3400-7.

8 Hyodo Y, Matsui K, Hayashi N, et al. IL-18 up-regulates perforin-mediated NK activity without increasing perforin messenger RNA expression by binding to costitutively expressed IL-18 receptor. J Immunol 1999;162:1662-8.

9 Ghayur T, Banrjee S, Hugunin M, et al. Caspase-1 processed IFN-gamma inducing factor and regulates LPS-induced IFN-gamma production. Nature 1997;386:619-23.

10 Takeda K, Tsutsui H, Yoshimoto T, et al. Defective NK cell activity and THI response in IL-18 deficient mice. Immunity 1998;8:383-90.

11 Sakao Y, Takeda K, Tsutsui H, et al. IL-18 deficient mice are resistant to endotoxin-induced liver injury but highly susceptible to endotoxic shock. Int Immunol 1999;11:471-4.

12 Tsuitsui H, Kayagaki N, Kuida K, et al. Caspase-1 independent, Fas-Fas ligand mediated IL-18 secretion from macrophages causes acute liver injury in mice. Immunity 1999:11:359.

13 Torigoe S, Ushio T, Okura S, et al. Purification and characterization of the human interleukin-18 receptor. J Biol Chem 1997;272:25737-42.

14 Thomassen E, Bird TA, Renshaw BR, et al. Binding of interleukin-18 to the interleukin-1 receptor homologous receptor IL-1 Rrpl leads to activation of signaling pathways similar to those used by interleukin-1. J Interferon Cytokine Res 1998;18:1077-88.
15 Born TL, Thomassen E, Bird TA, et al. Cloning of a novel receptor subunit, $\mathrm{AcPL}$, required for interleukin-18 signaling. J Biol Chem 1998;273:29445-50

16 Wesche $\mathrm{H}$, Henzel WJ, Shillinglaw W, et al. MyoD88: an adaptor that recruits IRAK to the IL-1 receptor complex. Immunity 1997;7:737-847.

17 Yang J, Lin Y, Guo Z, et al. The essetial role of MEKK3 in TNF-induced NF-kB activation. Nat Immunol $2001 ; 2: 620-4$.

18 Palanisamy K, Karen N, Ying W, et al. Defective interleukin (IL)-18-mediated natural killer and Thelper cell type 1 responses on IL-1 receptor-associated kinase (IRAK)-deficient mice. J Exp Med 1999;189:111129-38.

19 Barbulescu K, Becker C, Schlaak JF, et al. IL-12 and IL-18 differentially regulate the transcriptional activity of the human IFN-gamma promoter in primary CD4+ T lymphocytes. J Immunol 1998;160:3642-7.

20 Zhumabekov $T$, Corbella $P$, Tolaini $M$, et al. Improved version of the human CD2 minigene based vector for cell-specific expression in transgenic mice. $J$ Immunol Methods 1995; 185:133-40.

21 Davis LG, Dibner MD, Battey JF. Basic methods in molecular biology. New York: Elsevier, 1986.

22 Streetz K, Leifeld L, Grundmann D, et al. Tumor necrosis factor in the pathogenesis of human and murine fulminant hepatic failure. Gastroenterology 2000;1 19:446.

23 Bradham CA, Qian T, Streetz K, et al. The mitochondrial permeability transition is required for tumor necrosis factor-mediated apoptosis and cytochrome c release. Mol Cell Biol 1998;18:6353.

24 Finotto S, De Sanctis GT, Lehr HA, et al. Treatment of allergic airway inflammation and hyperresponsiveness by antisense-induced local blockade of GATA-3 expression. J Exp Med 2001;193:1247-60.

25 Galle PR, Hofman WJ, Walczak H, et al. Involvment of the CD95(APO-1/Fas) receptor and ligand in liver damage. J Exp Med 1995;182:1223.

26 Strand S, Hofmann WJ, Crambihler A, et al. Hepatic failure and liver cell damage in acute Wilson's disease involve CD95 (APO1/Fas) mediated apoptosis. Nat Med 1998;4:588-93.

27 Dao T, Otashi K, Kayano T, et al. Interferon gamma-inducing factor, a novel cytokine, enhances Fas ligand-mediated cytotoxicity of murine T helper 1 cells. Cell Immunol 1996;173:230-5.

28 Tsutsui H, Nakanishi K, Matsui K, et al. IFN-gamma inducing factor upregulates Fas ligand mediated cytotoxic activity of murine natural killer cell cloned. J Immunol 1996:157:3967-73.

29 Streetz K, Fregien B, Plumpe J, et al. Dissection of the intracellular pathways in hepatocytes suggests a role for Jun kinase and IFN regulatory facotr 1 in Con A induced liver failure. J Immunol 2001;167:514-23.

30 Blindenbacher A, Wang X, Langer I, et al. Interleukin 6 is important for survival after partial hepatectomy in mice. Hepatology 2003;38:674-82.

31 Rivera-Walsh I, Cvijic ME, Xiao G, et al. The NF-kappa B signaling pathway is not required for Fas ligand gene induction but mediates protection from activation-induced cell death. J Biol Chem 2000;275:25222-30.

32 Liu Z, Hu G, Goeddel H, et al. Dissection of TNF receptor 1 effector functions: JNK activation is not linked to apoptosis, while NF-kB activation prevents cell death. Cell 1996;87:565-76.

33 Rosenfeld ME, Prichard L, Shiojiri N, et al. Prevention of hepatic apoptosis and embryonic lethality in RelA/TNFR1 double knockout mice. Am J Pathol 2000;156:997-1007

34 Silverman N, Maniatis T. NFkB signaling pathways in mammalian and insect innate immunity. Gene Dev 2001;15:2321-42.

35 Karin M, Anning L. NF-kB at the crossroads of life and death. Nat Immunol 2002;3:221

36 Madrid LV, Wang CY, Guttridge DC, et al. Akt suppresses apoptosis by stimulating the transactivation potential of the RelA/p65 subunit of NFkB. Mol Cell Biol 2000;20:1626-38.

37 Madrid LV, Mayo MW, Reuther JY, et al. Akt stimulates the transactivation potential of the RelA/p65 subunit of NFkB through utilization of the iKB kinase and activation of the mitogen activated protein kinase p38. J Biol Chem $2001 ; 276: 18934-40$

38 Beg AA, Sha WC, Bronson RT, et al. Embryonic lethality and liver degeneration in mice lacking the relA component of NFkB. Nature 1995:376:167-9.

39 Ahmed-Choudhury J, Russell CL, Randhawa S, et al. Differential induction of nuclear factor-kappaB and activator protein-1 activity after CD40 ligation is associated with primary human hepatocyte apoptosis or intrahepatic endothelial cell proliferation. Mol Biol Cell 2003;14:1334-45.

40 Afford SC, Randhawa S, Eliopoulos AG, et al. CD40 activation induces apoptosis in cultured human hepatocytes via induction of cell surface fas ligand expression and amplifies fas-mediated hepatocyte death during allograft rejection. J Exp Med 1999;189:441-6.

41 Afford SC, Ahmed-Choudhury J, Randhawa S, et al. CD40 activationinduced, Fas-dependent apoptosis and NF-kappaB/AP-1 signaling in human intrahepatic biliary epithelial cells. FASEB J 2001;15:2345-54.

42 Yumoto E, Higashi T, Nouso K, et al. Serum gamma-interferon-inducing factor (IL-18) and IL-10 levels in patients with acute hepatitis and fulminant hepatic failure. J Gastroenterol Hepatol 2002;17:285-94. 


\section{PostScript}

\section{LETTERS}

\section{Platelet count/spleen diameter ratio as a predictor of oesophageal varices in alcoholic cirrhosis}

We read with great interest the article by Giannini et al (Gut 2003;52:1200-5) regarding platelet count/spleen diameter ratio as a noninvasive parameter to predict the presence of oesophageal varices in patients with liver cirrhosis. ${ }^{1}$ In patients with liver disease due to alcohol, platelet count is reduced due to the myelotoxic effect of alcohol. In the study, only $16.55 \%(24 / 145)$ of patients had liver cirrhosis due to alcohol. In the UK, alcohol is the commonest cause of liver cirrhosis.

We retrospectively studied endoscopy, haematology, and radiology reports of 40 patients who had been treated for alcohol induced cirrhosis at Homerton Hospital, London. Of these, 30 had oesophageal varices at endoscopy and 10 did not. The platelet count/spleen diameter ratio was calculated within two months of endoscopy.

The median platelet count/spleen diameter ratio in patients with varices was 537 (range 371-670) and with no varices 2229 (range 1542-3174). A platelet count/spleen diameter ratio of $<909$ had $100 \%$ sensitivity and specificity for the prediction of oesophageal varices in patients.

We have shown that this non-invasive method of predicting the presence of oesophageal varices through platelet count/spleen diameter ratio is reproducible in alcoholic cirrhotic patients

\section{T A Zimbwa, C Blanshard, A Subramaniam} Homerton University Hospital, London, UK

Correspondence to: Dr T A Zimbwa, Homerton University Hospital, Homerton Row, London E9 6SR UK; TrmnZimbwa@aol.com

\section{Reference}

1 Peck-Radosavljevic M. Thrombocyłopenia in liver disease. Can J Gastroenterol 2000;14(suppl D):60-6D.

\section{Diagnosis of hereditary non- polyposis colorectal cancer (HNPCC)}

The paper addressing the role of monogenic inheritance in the aetiology of colorectal cancer highlights the importance of achieving a meaningful working diagnosis of hereditary non-polyposis colorectal cancer (HNPCC) (Gut 2004;53:115-22). The diagnosis of HNPCC may be achieved in two ways:

(1) by equating the Amsterdam criteria with a clinical diagnosis,

(2) by compiling a comprehensive set of clinical, pathological, and molecular features that would together support the diagnosis of a specific condition caused by a germline mutation in a DNA mismatch repair gene such as hMLH1 or hMSH2.

It is clear that there is potential for considerable confusion if the label HNPCC is used in these very different ways.
The original Amsterdam criteria were not developed to serve as the diagnostic criteria for HNPCC but merely to introduce a uniform approach to the selection of families for collaborative studies. ${ }^{1}$ It was originally considered that the criteria would be relatively specific rather than sensitive. However, colorectal cancer is a common disease, and the finding of three close relatives affected by bowel cancer within a single large family would not necessarily equate with a specific autosomal dominant disorder, even if one of the subjects happened to be aged below 50 years. Ponz de Leon and colleagues (Gut 2004;53:115-22) show in table 3 that families meeting the Amsterdam criteria but having cancers that are DNA microsatellite stable do not display the clinical features of HNPCC (see below). This is not altogether surprising. In fact it was shown nearly 10 years ago that colorectal cancers in such Amsterdam criteria positive kindreds were frequently DNA microsatellite stable and that the clinical and pathological features of these families were unlike HNPCC (see below). ${ }^{2}$ Of course, the latter findings do not preclude a genetic basis for such clustering of colorectal cancer within a family.

The diagnostic features of HNPCC have accumulated and been refined over time. HNPCC is now defined by a set of clinical, pathological, and molecular features that encompass: a family history of colorectal cancer, a particular spectrum of extracolonic neoplasms, multiple colorectal neoplasia, early onset neoplasia, particular histological features among colorectal cancers, the presence of DNA microsatellite instability, loss of expression of DNA mismatch repair proteins as shown by immunohistochemistry, and a germline mutation in a DNA mismatch repair gene. ${ }^{3}$ It may not be possible to identify the germline mutation in all families, even when cancers show evidence of deficient DNA mismatch repair. This is merely the result of technical limitations which should not preclude a diagnosis when the other features are met. Close mimicry of HNPCC may occur when hMLHI has been methylated, perhaps through a familial predisposition to this chemical modification of DNA. ${ }^{4}$ In the latter instance colorectal cancers may develop in a background of multiple hyperplastic polyps.

Now that there is international agreement that the term HNPCC equates to a specific clinicopathological entity, ${ }^{3}$ there would seem to be little merit in applying the diagnosis when only the limited set of clinical features encompassed by the Amsterdam criteria is met. Reporting of a family history of colorectal cancer has been shown to be unreliable. ${ }^{6}$ What would we think of a judge who chose to base his verdict only on hearsay and rumour and to ignore all evidence of a scientific nature? Why should a family be burdened unnecessarily with the label HNPCC and all its ramifications and how may epidemiological research be advanced by the application of a vague and unreliable diagnostic label?

J R Jass

Correspondence to: Professor J R Jass, Department of Pathology, Duff Medical Building, 3775 University st, Montreal, Quebec, Canada H3A 2B4; jeremy.jass@mcgill.ca

\section{References}

1 Vasen HFA, Mecklin J-P, Khan PM, et al. The international collaborative group on hereditary non-polyposis colorectal cancer (ICG-HNPCC). Dis Colon Rectum 1991;34:424-5.

2 Jass JR, Cottier DS, Jeevaratnam $P$, et al. Diagnostic use of microsatellite instability in hereditary non-polyposis colorectal cancer. Lancet 1995;346:1200-1.

3 Vasen HF, Watson P, Mecklin J-P, et al. New clinical criteria for hereditary nonpolyposis colorectal cancer (HNPCC, Lynch syndrome) proposed by the International Collaborative Group on HNPCC. Gastroenterology 1999;116:1453-6.

4 Frazier ML, Xi L, Zong J, et al. Association of the $\mathrm{CpG}$ island methylator phenotype with family history of cancer in patients with colorectal cancer. Cancer Res 2003:63:4805-8.

5 Jass JR, Cottier DS, Pokos V, et al. Mixed epithelial polyps in association with hereditary non-polyposis colorectal cancer providing an alternative pathway of cancer histogenesis. Pathology 1997;29:28-33.

6 Mitchell RJ, Brewster D, Campbell $H$, et al. Accuracy of reporting of familial history of colorectal cancer. Gut 2004;53:291-5.

\section{Author's reply}

In reply to the letter of Dr Jass we would like to make the following points.

We agree with Dr Jass that since the new discoveries and advances in our knowledge of hereditary non-polyposis colorectal cancer (HNPCC), the diagnosis of the syndrome has become a matter of conscience. The Amsterdam clinical criteria are useful but not definitive in the diagnosis of the disease, and other parameters (pathological, biological, molecular) must be taken into account. Besides, family history is not reliable in every case. So, what should we do?

We believe that, as a first step, the classical clinical approach of tracing a genealogical tree focused on malignancies in the family should be pursued for each proband, to attempt to estimate the probability of disclosing an hereditary form of colorectal cancer. In doing this, we do not label a family as HNPCC on clinical grounds alone, but we think that such families should be studied and followed with particular attention to obtain other clues and proof of the syndrome and to provide appropriate counselling measures.

From an epidemiological point of view, we agree that estimation of the frequency of the syndrome based on clinical criteria should be considered with caution, but it is the only practical way. When a population approach was used, defining the microsatellite status of all registered tumours in a period and then searching for constitutional mutations in patients with unstable tumours, as high as $2.7 \%$ of patients with colorectal tumours were labelled as HNPCC. ${ }^{1}$ These values are similar to those obtained with clinical criteria (Gut 2004;53:115-22) although not confirmed in other settings. ${ }^{2}$ Therefore, we believe that it is not a burden for the family if we choose to follow them with special care. Moreover, it has been demonstrated that active follow up can reduce the number of newly developed carcinomas in families with HNPCC (not all with a molecular diagnosis) and reduce cancer mortality. ${ }^{3}$ 
L Roncucci, M Ponz de Leon, P Benatti, F Borghi, M Pedroni, A Scarselli, C di Gregorio, L Losi, A Viel, M Genuardi, G Abbati, G Rossi, M Menigatti, G Ponti University of Modena and Reggio Emilia, Modena,

Correspondence to: Professor L Roncucci, Department of Internal Medicine, University of Modena and Reggio Emilia, Via Del Pozzo, 71 Modena 41100 Italy; roncucci@unimo.it

\section{References}

1 Salovaara R, Loukola AA, Kristo P, et al Population-based molecular detection of hereditary nonpolyposis colorectal cancer. J Clin Oncol 2000; 18:2193-200.

2 Percesepe A, Borghi F, Menigatti M, et al Molecular screening for hereditary nonpolyposis colorecal cancer: a prospective, population-based study. J Clin Oncol 2001;19:3944-50.

3 Jarvinen $\mathrm{HJ}$, Aarnio M, Mustonen $\mathrm{H}$, et al. Controlled 15-year trial on screening for colorectal cancer in families with hereditary nonpolyposis colorectal cancer. Gastroenterology 2000; 116:829-34.

\section{Bone density loss in Crohn's disease: role of TNF and potential for prevention by bupropion}

We note with interest the demonstration by Card et al that the increased hip fracture rate in Crohn's disease (CD), and by inference the diminished bone density commonly noted in $C D$, is only to a minor degree secondary to iatrogenic corticosteroid use (Gut 2004;53;251-5). The subject of bone mineral density loss in CD has been recently reviewed; tumour necrosis factor $\alpha(\mathrm{TNF}-\alpha)$ is suspected of being an important mediator of this loss. ${ }^{12}$ Evidence has been published for localised overproduction of TNF- $\alpha$ being largely responsible for the bone loss seen in rheumatoid arthritis, ${ }^{3}{ }^{4}$ psoriatic arthritis, multiple myeloma, ${ }^{6}$ hip prosthesis loosening, periodontal disease, ${ }^{8}$ and spondyloarthropathies. ${ }^{9}$ Anti-TNF- $\alpha$ antibody has been shown to slow the bone loss of spondyloarthropy and rheumatoid arthritis. ${ }^{3} 10$

We have found that the commonly used antidepressant bupropion can induce remission in $\mathrm{CD}^{11}{ }^{12}$ and have found that bupropion can lower TNF- $\alpha$ levels. ${ }^{13}$ If bupropion is found to be effective in CD and to lower TNF- $\alpha$ levels in large trials, it might be considered for use in bone loss and osteoporosis, in $\mathrm{CD}$ or otherwise.

R E Kast, E L Altschuler

Department of Psychiatry, University of Vermont Vermont, USA

Correspondence to: Dr R E Kast, Department of Psychiatry College of Medicine, University of Vermont, 2 Church St, Burlington, Vermont 05401, USA rekast@email.com

\section{References}

1 Lichtenstein GR. Evaluation of bone mineral density in IBD: current safty focus. Am J Gastroenterol 2003;98(suppl 12): S24-30.

2 Nanes MS. TNF-alpha: molecular and cellular mechanisms in skeletal pathology. Gene 2003;321:1-15

3 Bingham $\mathrm{CO}$ iii. The pathogenesis of rheumatoid arthritis: pivotal cytokines involved in bone degradation and inflammation. J Rheumatol Suppl 2002;65:39.
4 Goldring SR. Pathogenesis of bone and cartilage destruction in rheumatoid arthritis. Rheumatology 2003;42(suppl 2):ii 1 1-6.

5 Ritchlin CT, Haas-Smith SA, Li P, et al. Mechanism of TNF-alpha and RANKL mediated osteoclastogenesis and bone resorption in psoriatic arthritis. J Clin Invest 2003; 1 11:821-31.

6 Jurisic V, Colovic M. Correlation of sera TNFalpha with percentage of bone marrow plasma cells, LDH, beta 2 micro globulin, and clinical stage in multiple myeloma. Med Oncol 2002; 19:133-9.

7 Campbell PA, Wang M, Amstutz HC, et al. Positive cytokine production in failed metal on metal total hip replacements. Acta Orthop Scand 2002;73:506-12.

8 Graves DT, Cochran DN. The contribution of IL-1 and TNF-alpha to periodontal tissue destruction. I Periodont 2003;74:391-401.

9 Allali $F$, Breban $M$, Porcher $R$, et al. Increase in bone mineral density in patients with spondyloarthropathy treated with anti-TNF-alpha. Ann Rheum Dis 2003;62:347-9.

10 Geimold AM. New indications for treatment of chronic inflammation by TNF-alpha blockade. Am J Med Sci 2003;325:75-92.

11 Kast RE, Altschuler EL. Remission of Crohn's disease on bupropion. Gastroenterology 2001;121:1260-1

12 Kane S, Altschuler EL, Kast RE. Crohn's disease remission on bupropion. Gastroenterology 2003;125:1290.

13 Kast RE, Altschuler EL. TNF in hepatitis B: potential role for bupropion. J Hepatol 2003;39:131-3.

\section{Poor bowel preparation: a poor excuse}

In the article by Bowles et al (Gut 2004;53: 277-83), poor bowel preparation is cited as the cause of $19.6 \%$ of failures to achieve complete colonoscopy. Similarly high values of up to $35 \%$ have been quoted elsewhere

In a personal series of 1195 procedures, only 19 of 197 (9.6\%) failures were attributed to this cause. This difference was highly significant $(\mathrm{p}<0.001)$.

As choice of laxative agent and population demographics are similar, one could conclude that either Guernsey patients are more compliant with or responsive to bowel preparation or that minimal faecal residue present in a difficult colon is used as a nonoperator dependent reason (excuse?) for what is basically a technique failure.

I suspect the same applies to "patient discomfort" which, at $34.7 \%$, is also significantly higher $(\mathrm{p}<0.001)$ than my own values of $31 / 197(15.7 \%)$. My typical sedation is $5 \mathrm{mg}$ midazolam and $10 \mathrm{mg}$ nalbuphine.

I confess that my usage of these excuses has declined over the years as my success rate has climbed! It is time to get training and be honest.

P J Mullen

Correspondence to: Dr P J Mullen; The Princess Elizabeth Hospital, Guernsey GY2 4AP, UK; chateau@guernsey.net

\section{Sporadic duodenal adenoma and} colorectal neoplasia

We read with great interest Murray et al's article concerning the association between sporadic duodenal adenoma and colorectal neoplasia (Gut 2004;53:261-5)

We have also noted a lack of published literature regarding sporadic duodenal adenomas, with the exception of the two reports identified by the authors, ${ }^{12}$ as well as a more recent case series, ${ }^{3}$ and therefore welcome the addition of their large case series and comparison group. Although there is the potential for bias in the detection of colorectal neoplasia in their duodenal adenoma cases, as the indications for colonoscopy were somewhat different between cases and controls (with almost one third of cases of duodenal adenomas being endoscoped for investigation of anaemia or melaena), overall their data support a clinically relevant association between duodenal and colonic adenomas.

These results are corroborated by our own recent experience at Leeds General Infirmary where we have studied the natural history of duodenal adenoma. We also examined histopathology records and case notes for patients with sporadic duodenal adenomas between 1990 and 2002 (excluding familial adenomatous polyposis and hereditary non-polyposis colorectal cancer). We identified 35 cases; 16 males and 19 females (mean age 65 years). The majority of these were noted incidentally at upper gastrointestinal endoscopy or endoscopic retrograde cholangiopancreatography, with a similar range of indications for examination as those noted by Murray et al. Using the criteria stipulated by the authors, $25(71 \%)$ of the adenomas were advanced. Of the 35 patients in our series, 11 underwent colonoscopic examination. This revealed a synchronous colonic adenoma in four patients $(36 \%)$, three of which were tubulovillous adenomas and therefore advanced according to the aforementioned criteria, and the fourth a tubular adenoma. This compares with a reported rate of colonic neoplasia of $25.5 \%$ in a series of 1000 consecutive unselected patients attending the Leeds General Infirmary for colonoscopy. ${ }^{4}$ Unlike Murray et al, we did not find any colonic carcinomas in our patients. This discrepancy presumably relates to the fact that both series are relatively small and the confidence intervals are likely to be wide, much as they found.

Unfortunately, Murray et al provide no follow up data relating to the duodenal adenomas in their series. We have clinical data for all our cases, with a median duration of follow up of four years. Seventeen of the 35 adenomas were removed (six surgically, four by endoscopic mucosal resection (EMR), three snared, three during biopsy, and one by argon photocoagulation), and of these, two patients had a recurrence (one treated by EMR, the other kept under surveillance), and all were alive at the time of review (median time from diagnosis 58 months). Among the 18 patients who had no therapy for their polyp, 10 died (median length of follow up 43 months). One patient who had a tubulovillous adenoma with high grade dysplasia developed a $3 \mathrm{~cm}$ adenocarcinoma of the first part of the duodenum five months after initial diagnosis and underwent a Whipple's procedure but died 12 months later from metastatic disease. The other patients died from unrelated causes.

Despite published literature that suggests duodenal polyps have no prognostic importance, ${ }^{5}$ we believe that the optimal management of duodenal adenomas is early excision and follow up. We also concur that there is an association between sporadic duodenal adenomas and colonic neoplasia, and agree entirely that all patients found to have sporadic duodenal adenomas should undergo colonoscopy. However, owing to reasons of study size and bias in the comparison groups, the magnitude of this association cannot be accurately determined. Furthermore, the reasons for this association are as yet unclear, and 
molecular studies are required to further investigate.

A C Ford, O Rotimi, S M Everett Centre for Digestive Diseases, Leeds General Infirmary, Leeds, UK

Correspondence to: Dr A C Ford, Centre for Digestive Diseases, Leeds General Infirmary, Great George St, Leeds LS1 3EX, UK; alexf12399@yahoo.com

\section{References}

1 Hochter W, Weingart J, Seib HJ, et al. Duodenal polyps. Incidence, histologic substrate, and significance. Dtsch Med Wochenschr 1984; 109:1183-6.

2 Jepsen JM, Persson M, Jakobsen NO, et al. Prospective study of prevalence and endoscopic and histopathologic characteristics of duodenal polyps in patients submitted to upper endoscopy. Scand J Gastroenterol 1994;29:483-7.

3 Chong KC, Cheah WK, Lenzi JE, et al. Benign duodenal tumors. Hepatogastroenterology 2000;47:1298-300.

4 Rembacken BJ, Fuiji T, Cairns A, et al. Flat and depressed colonic neoplasms: a prospective study of 1000 colonoscopies in the UK. Lancet 2000;35:1211-14

5 Burke CA, van Stolk RU. Diagnosis and management of gastroduodenal polyps. Surg Oncol Clin North Am 1996:5:589-607.

\section{Dysbiosis as a prerequisite for IBD}

We thank Dr Szilagyi for his very interesting comments in his letter regarding dysbiosis in inflammatory bowel disease (IBD).

The main question remains as to why beneficial bacteria such as bifidobacteria might be lacking in IBD (Gut 2004;53:1-4) Dr Szilagyi describes an interesting hypothesis of colonic prebiotic deficiency as a possible mechanism for dysbiosis. A suggestion is made that this deficiency could be linked to increased proximal small intestinal permeability with enhanced absorption of prebiotic substrate, causing a relative deficit of prebiotics distally. Certainly, the phenomenon of increased small bowel permeability has been documented in Crohn's disease; its importance in ulcerative colitis is less clear however. As lactulose is not a major component of the normal human diet, long term epidemiological dietary trends should also have to be consistent with a significantly decreased intake of common prebiotic substrates, if this hypothesis is correct. Unfortunately, there is currently little clinical evidence to support or refute this theory, as dietary studies in IBD have been subject to many biases inherent in their study design.

Bifidobacteria are strongly glucidolytic and show nearly no growth in the absence of fermentable sugars or polysaccharides. One group of good substrates are mucins, which are often increased in Crohn's disease. Perhaps differences in ease of glycosylation between some substrates affect the ability of the flora to metabolise them. This has not been well studied in IBD. There are also likely to be other influences on the host's dominant flora, including genetic factors. Observations among some of our healthy cohorts with low levels of bifidobacteria have revealed highly variable responses of bifidobacterial counts to prebiotic treatments. Whether a poor response might represent a risk factor for IBD is also an interesting question.

C P Tamboli
Division of Gastroenterology, Department of Internal Medicine, University of lowa Hospitals and Clinics, lowa City, USA

C Neut

Laboratoire de Bacteriologie, Faculté de Pharmacie, Lille, France, and INSERM EPIO1 14, CHU Lille, France

P Desreumaux, J F Colombel

Service d'Hepatogastroenterologie, Hopital Huriez, and INSERM EPIO1 14, CHU Lille, France

Correspondence to: Dr C P Tamboli, Division of Gastroenterology, University of lowa Hospitals and Clinics, 200 Haskins Dr, lowa City 52242, USA; cyrus-tamboli@uiowa.edu

\section{Reference}

1 Szilagyi A. Dysbiosis as a prerequisite for IBD (electronic response to Tamboli et al. Dysbiosis in inflammatory bowel disease. Gut. 2004;53: 1-4), http://gut.bmijournals.com/cgi/eletters/53/1/ $1 \# 244$.

\section{Remarkable difference in the} mode of HCV transmission among haemodialysis patients and

\section{IVDAs}

We read with great interest the letter by Saxena et al (Gut 2003;52:1656-7). We would however take issue with their hypothesis, as we indeed believe in the remarkable differences in the mode of hepatitis $\mathrm{C}$ virus (HCV) transmission in these two high risk groups. Studies have reported a value of $70-90 \%$ for the prevalence rate of HCV infection among intravenous drug abusers (IVDAs). ${ }^{.}$The main source of HCV infection in this population is sharing contaminated needles. The incidence of rapid acquisition of HCV infection following initial intravenous drug use within the first year has been reported to be as high as $80 \%{ }^{2} \quad$ Moreover, syringe exchange programmes have been shown in some studies to reduce the risk of infection. ${ }^{3}$ In the study in India, ${ }^{4}$ as also mentioned by Saxena et al, although the syringe exchange programme was not effective in the prevention of HCV infection, it was effective in controlling hepatitis B virus (HBV) and human immunodeficiency virus (HIV) infection. Moreover, in these types of studies and programmes, consideration should be given to the fact that IVDAs are a special population with particular behaviour patterns. As they often have no strong motivation to be educated, they may deny their high risk behaviour, even within an instructive programme.

On the other hand, the main route of HCV transmission in haemodialysis (HD) patients seems to be transfusion, as the HCV infection incidence in haemodialysis units has been declining following implementation of blood product screening in developed countries. The Centers for Disease Control and Prevention (CDC, Atlanta, Georgia, USA) reported a nationwide prevalence of $\mathrm{HCV}$ infection in HD patients of $8.9 \%$ in a recent update. ${ }^{5}$ Thus the prevalence and incidence of HCV infection in HD patients appear not to be as high as that for IVDAs. However, we are in agreement with Saxena et al that nosocomial transmission should not be neglected in HD sites. The study by Okuda et al showed that education of staff members and application of adhesive pads at the time of needle withdrawal in HD sites resulted in a decrease in the incidence of HCV infection to zero, and no new HCV infected cases were reported for over a year in 730 patients on maintenance HD. ${ }^{6}$
The other point to note is the fact that coinfection with HCV and HBV is common in IVDAs $^{7}$ but less prevalent in HD patients. This interesting point may highlight evidence of another difference in the main transmission route of infection in these two populations.

S M Alavian, B Hajarizadeh

Tehran Hepatitis Center, Tehran, Iran

Correspondence to: Dr S M Alavian, PO Box 141553651, Tehran, Iran; manager@iranhepgroup.info

\section{References}

1 MacDonald M, Crofts N, Kaldor J. Transmission of hepatitis $C$ virus: rates, routes and cofactors. Epidemiol Rev 1996; 18:137-48.

2 Garfein RS, Vlahov D, Galai N, et al. Viral infections in short-term injection drug users: the prevalence of the hepatitis $C$, hepatitis $B$, human immunodefiency, and human T-lymphocyte viruses. Am J Public Health 1996:86:655-61

3 Hagan H, Des Jarlais DC, Friedman SR, et al. Reduced risk of hepatitis $B$ and $C$ among participants in a syringe exchange program. Am J Public Health 1995:85:1531-7.

4 Sarkar K, Mitra S, Bal B, et al. Rapid spread of hepatitis $C$ virus and needle exchange programme in Kolkata, India. Lancet 2003;361:1301-2.

5 Centers for Disease Control and Prevention. Recommendations for preventing transmission of infections among chronic hemodialysis patients. MMWR Morb Mortal Wkly Rep, 2001;50(RR 5): 1-43.

6 Okuda KH, Hayashi H, Kobayashi S, Irie Y. Mode of hepatitis $\mathrm{C}$ infection not associated with blood transfusions among chronic hemodialysis patients. J Hepatol 1995;23:28-31.

7 Sterling RK. Triple infection with human immunodefiency virus, hepatitis $C$ virus, and hepatitis $B$ virus: A clinical challenge. Am J Gastroenterol 2003;98:2130-4.

\section{COX 2 inhibition and bowel strictures}

The letter by Mir et al (Gut 2004;53:154) caught our attention and seems to have caught the editorial staff dozing.

Mir et al present a patient who had been regularly taking conventional non-steroidal anti-inflammatory drugs (NSAIDs) for 26 years for axial spondylarthropathy and ascribe the presence of distal ileal stricturing and ulceration solely to the use of a cyclooxygenase 2 (COX 2) selective inhibitor that had been taken for two years. The differential diagnosis of ileal lesions in spondylarthropathy is quite clear. Firstly, as the authors themselves stated, strictures are associated with long term use of conventional NSAIDs. ${ }^{1}$ The 26 year use of NSAIDs by the patient is most significant. While such lesions are usually more proximal, slow release formulations of NSAIDs can give rise to distal disease such as in this circumstance. The authors do not specify if this is the case. NSAID induced ulcers, when established, may take years to heal, such that the two year time lag between stopping NSAIDs and clinical symptoms is not unexpected.

Secondly, spondylarthropathy is itself associated with ileitis in $30-70 \%$ of cases, irrespective of NSAID intake. Most cases are asymptomatic but some cases proceed to stricturing disease. ${ }^{2}$ De Keyser et al, in particular, have made a case for spondylarthropathic ileitis being a form of subclinical Crohn's disease. ${ }^{3}$ Finally, axial spondylarthropathy may be an extraintestinal manifestation of $5-10 \%$ of cases of inflammatory bowel disease. ${ }^{2}$ It is difficult to exclude this as the cause of both the recent ulceration and 
stricturing because histology does not always show typical (for example, granulomatous) changes. To date, the only small bowel pathology reported from selective COX 2 inhibition (or absence) is of ileocaecal inflammation and perforation (not stricturing) in animal studies. ${ }^{4}$ Hence, while it is a remote possibility that COX 2 inhibition may have given rise to the lesions in this patient, these are far more likely to be due to other factors.

L P Maiden King's College Hospital, London, UK

I Bjarnason

Department of Medicine, Guy's, King's, and St Thomas' School of Medicine, Bessemer Rd, London,

Correspondence to: Dr L P Maiden; Ipmaiden@doctors.net.uk

\section{References}

1 Bjarnason I, Hayllar J, Macpherson A, et al. Side effects of nonsteroidal anti-inflammatory drugs on the small and large intestine in humans. Gastroenterology, 1993;104:1832-47.

2 Smale S, Natt RS, Orchard T, et al. Spondylarthropathy and inflammatory bowel disease. Arthritis Rheum 2001;44:2728-36.

3 De Keyser F, Baeten D, Van den Bosch F, et al. Gut inflammation and spondyloarthropathies. Curr Rheumatol Rep 2002;4:525-32.

4 Sigthorsson G, Simpson RJ, Walley $M$, et al. COX-1 and 2, intestinal integrity and pathogenesis of NSAID-enteropathy in mice. Gastroenterology 2002; 122:1913-23.

\section{Intravenous pulse cyclophosphamide therapy in Crohn's disease and ulcerative colitis}

The management of refractory severe inflammatory bowel disease (IBD) is still unresolved. We read with interest the article by Stallmach et al on the safety and efficacy of intravenous pulse cyclophosphamide in acute steroid refractory IBD (Gut 2003;52:377-82).

In common with other disease, the aims of therapy in IBD fall into three categories:

(a) induction of remission;

(b) maintenance of remission; and

(c) prevention of relapse, all of which should be undertaken with minimal mortality and morbidity either from the disease itself or from therapy.

Based on previous observations of improvement in autoimmune diseases (that is, vasculitides), cyclophosphamide can be a primary cytotoxic drug: pulse intravenous cyclophosphamide is probably equally effective as oral cyclophosphamide in inducing remission and this remission is usually maintained by continuing cyclophosphamide for 3-6 months before changing to a combination of other oral therapies. Therapy must be continued to prevent relapse and for maintenance.

We would like to report on some other cases. In our cohort, we included patients with Crohn's disease (CD) and ulcerative colitis (UC). Four patients with CD and four with UC were diagnosed according to standard criteria. They did not respond to conventional therapy and therefore we administered pulse cyclophosphamide therapy monthly (for six months, $800 \mathrm{mg}$ each time). Most patients went into remission after the second/third cyclophosphamide pulse. Disease activity decreased, there were no side effects, no toxicity, and all patients achieved long lasting remission. For maintenance, patients with $\mathrm{CD}$ were treated with methotrexate ( $10 \mathrm{mg} /$ week) and patients with UC were given azathioprine (100 mg/day). Remission appears to be stable.

These findings suggest that aggressive immunosuppressive therapy may be useful in some refractory patients, and further controlled study should be considered in order to fully evaluate this type of treatment as a potential therapy in IBD.

IBD continue to pose a challenge to clinicians. Over the past few years there have been significant advances in our understanding of pathogenesis and treatment. These advances will hopefully lead to more specific and targeted treatments, with consequent improvement in clinical outcomes. Intravenous pulse cyclophosphamide may be a safe and effective treatment in patients with severe IBD unresponsive to "conventional" treatment. It is also recommended as a firstline adjunct to, or replacement for, systemic corticosteroids in the treatment of IBD.

Z Barta, L Toth, G G Szabo, G Szegedi, M Zeher

University of Debrecen, Debrecen, Hungary

Correspondence to: Z Barta, 3rd Department of Medicine, University of Debrecen, Moricz Zs krt, 22 Debrecen, Hungary; barta@iiibel.dote.hu

\section{Reference}

1 Watts RA, Scott DG, Pusey CD, et al. Vasculitisaims of therapy. An overview. Rheumatology (Oxford) 2000;39:229-32.

\section{CORRECTION}

In the paper by Finotto et al (Gut 2004;53:392-400), one of the author name's appeared incorrectly. The author name which was printed as R Khosravi-Fahr should have appeared as R Khosravi-Far.

\section{NOTICES}

\section{British Society of Gastroenterology Paul Brown Travel Fellowships}

The Paul Brown Travel Fellowships are awarded by the Endoscopy Committee of the BSG. They are intended to assist trainee gastroenterologists and established consultants in visits to units outside the United Kingdom for specialist experience and training in endoscopy.

Specialist registrars who have not achieved their CCST are expected to have the approval of their Postgraduate Dean and their Regional Training Director when they apply for a Travel Fellowship. Applicants are expected to provide confirmation that they have been accepted for training in the unit that they wish to visit.

Successful applicants will be expected to provide a brief written report to the Endoscopy Committee of the outcome of their visit.
Application forms are available from the British Society of Gastroenterology Office, 3 St Andrew's Place, London NWl 4LB. Email: bsg@mailbox.ulcc.ac.uk

\section{$8^{\text {th }}$ Southeast European Symposium of Paediatric Surgery}

The $8^{\text {th }}$ Southeast European Symposium of Paediatric Surgery will focus upon 'Infectious Problems in Paediatric Surgery.' The event will be held between 24-25 September 2004, at the University of Graz, Austria. For further information, please contact: Professor M E Höllwarth, Department of Paediatric Surgery, Medical University of Graz, Austria, Auenbruggerplatz 34, 8036 Graz; tel: + 43 316385 3762; fax: tel: + 43316385 3775; e-mail: kinderchirurgie@uni-graz.at.

\section{World Congress on Gastrointestinal Cancer}

The World Congress on Gastrointestinal Cancer will be held in Barcelona, Spain, on 16-19 June 2004. For further information, please contact Coleson Chase (tel: +1770751 7332; fax: +1 770751 7334; e-mail: c.chase@imedex.com; website: www. worldgicancer.com).

\section{Advances in the Inflammatory Bowel Diseases}

The conference for advances in the inflammatory bowel diseases will be held in Chicago, Illinois, USA on 8-9 October 2004. For further information, please contact: Coleson Chase (tel: +1 770751 7332; fax: +1 7707517334 ; e-mail: c.chase@imedex. com; website: www.imedex.com/calendars/ therapeutic.htm).

\section{$12^{\text {th }}$ European Symposium on Neurogastroenterology and Motility}

The $12^{\text {th }}$ European Symposium on Neurogastroenterology and Motility will be taking place at Robinson College, Cambridge, UK. The symposium will be taking placed on 1518 September 2004.

On Wednesday 15 September, there will be a postgraduate teaching day. This will cover established and evolving assessments of esophageal, gastric and intestinal function, visceral sensitivity and brain responses. Basic science techniques including electrophysiology, imaging of gut movements and neural activation will be covered in the afternoon. Finally there will be a session on GI pharmacology covering cytokines, capsaicin and tachykinins.

On Thursday 16 September through to Saturday 18 September midday, the main meeting will be held. This will include symposia, oral free papers and poster rounds. The symposia will be designed to move from basic science to clinical practice and will include sessions on stress and the gut, appetite and obesity, serotonin and inflammation, and inflammation and GI motility. There will also be state of the art lectures and prize presentations.

For registration and further information, please see the website www.neurogastro.org and follow links for '12th European Symposium on Neurogastroenterology and Motility.' Please contact the conference organizers at: Confrex, PO Box 21, Rottingdean, East Sussex, BN2 8WZ (tel: +44(0)1273 302200; fax: +44(0)1273 302334; e-mail: confrex@ easynet.co.uk). 